\title{
単杭の鉛直・水平振動特性の一簡易評価法 \\ A SIMPLIFIED ESTIMATION FOR CHARACTERISTICS OF SINGLE PILES UNDER VERTICAL AND HORIZONTAL VIBRATIONS
}

\author{
野添久視*, 日下部 馨**, 福 住忠裕*** \\ Hisashi NOZOE, Kaoru KUSAKABE and Tadahiro FUKUSUMI
}

\begin{abstract}
For single piles under vertical and horizontal vibrations, dynamic Winkler stiffnesses of subgrade reaction on pile circumference and at pile tip are proposed as simple expressions. A simplified estimation for vibrational characteristics of impedances and receptances at pile head presented by solving equations of motion of the pile as rod and Timoshenko's beam and by introducing the proposed subgrade reactions. It is verified that this method is sufficiently accurate in the practical situation from comparison with the rigorous and other solutions and this application to a building suported on piles in a case history is readily useful.
\end{abstract}

Keywords : simplified estimation, impedance, receptance, soil-pile interaction, vertical vibration, hori. zontal vibration

簡易評価法, インピーダンス, 伝達関数, 杭と地盤の相互作用, 鉛直振動, 水平振動

\section{1. 序 論}

軟弱な地盤上に建設される杭基礎で支持された構造物 の地震時の挙動を把握する上で; 杭一地盤系における杭 頭での複素剛性 (インピーダンス).および地動入力によ る杭頭の応答（伝達関数）が構造物との連成時に重要な 役割を演じるため，近年，動的相互作用を考慮した杭一 地盤系のこれらの動的特性に関して数多くの研究が報告 されている。解析パラメータが数多く含まれ複雑な構造 物一杭一地盤系の動的相互作用問題において，さまざまな 動的特性の評価を精度よく得るには一般に膨大な演算時 間と経費が伴うので，系統的な洞察を要する耐震設計等 において基本的な動的特性をより簡便に把握できる夷用 的評価法が切望されている。本論文では杭一地盤系の弾 性解析に立脚し，杭先端が基盤に固定された杭を支持杭 (end bearing pile), 杭先端が可動する杭を浮杭 (floating pile) と称し，振動数領域における相互作用 問題を取扱う。

既往の杭一地盤系の解析的研究において, その解析結 果から得られる動的特性の表現として, 図表や数表によ るものが一般に多く見られるが，ここでは構造物との連 成時に必要な杭頭での動的特性を簡便に得られる実用的 な評価法に関する研究に注目して取り上げる。杭頭での インピーダンス (またはコンプライアンス), 伝達関数
などの動的特性の簡便な評価法として，1）Winkler 夕 イプ評価法, 2)統計的評価法の 2 つに大別してとらえる。 1) Winkler タイプ評価法は, Terzaghi の先駆的な研 究1)に見られるように，杭周に作用する地盤反力（相互 作用力)をその作用点にのみ依存する地盤反力係数(ウィ ンクラば好）と変位の積で表現できるとする Winkler の概念 (1867) に基づく力学的モデルの近似解法から得 られる評価法で, 古くから静的問題において弾性支承梁 の曲げ理論として展開し, 地盤反力係数の評価の問題と して取り上げられてきた。実験的研究から地盤反力係数 の実用的な経験式が種々提案されており，この評価法は 現在では取扱いの簡便さから，無限長の杭を対象とした Chang や杭頭・杭先端の境界条件を考慮した杉村 ${ }^{2}$ なよ゙ の理論解を適用して実施設計 ${ }^{31.4}$ にも取り入れられてい る。杭周の横 (水平) 方向地盤反力係数の半解析的な簡 易式としては; 地表面上の無限長梁の柔性を考虑した Vesić による評価値を 2 倍し柔で長い杭に適用可能にし たFrancis ${ }^{5)}$ の研究がある。半無限地盤中の浮杭の弾性 解析に関して, 軸方向荷重を受ける浮杭では, Butterfield $ら^{6}$ が杭周に作用するせん断応力（鉛直方向地盤反 力）分布について，横方向荷重を受ける浮杭では， Banerjee ら”が杭周の横方向地盤反力分布について触れ ているが, 横方向地盤反力係数の簡易評価としては,

\footnotetext{
*広島_工業大学工学部建築学科

神戸大学工学部建築学科

神戸大学工学部建築学科

Dept. of Architecture, Faculty of Engineering, Hiroshima Institute of Technology

Dept. of Architecture, Faculty of Engineering, Kobe Univ.

Dept. of Architecture, Faculty of Engineering, Kobe Univ.
} 
Poulos $^{8)}$ が弾性支承梁理論の結果と比較検討し，㴊な 浮杭に対する簡易式の 1 例を示している程度である。そ の後, 杭周の鉛直方向地盤反力係数の簡便な評価法が Randloph ら ${ }^{9}$ によって静的平面ひずみ解から杭の長さ 径比と地盤のポアソン比を取り入れた簡易式として提案 されているが,柔で長い杭に対して問題が残されている。 このように杭周における鉛直方向および水平方向の地盤 反力係数に杭の長さ径比や杭の柔性などを考慮した簡便 な評価法に関して十分ではない。

一方, 動的問題において, Penzien ら ${ }^{10)}$ は水平振動す る支持杭に対して地盤反力を Mindlin 解による静的 ウィンクラばねとして集中質量系モデルに取り入れてい る。Novak は水平振動または鉛直振動する支持杭 ${ }^{11} に$ 対して Branov の動的平面ひずみ解による動的ウィンク ラばねを適用し,さらに杭先端には半無限弹性地盤上の 剛円盤に対する Bycroft の動的解による複素ばねを取り 入れて鈆直振動する浮杭 ${ }^{12)} に も$ 適用している。また，水 平振動する多層地盤中の支持杭の杭頭加振および地動入 カに関して, Takemiya ら ${ }^{133}$ は動的平面ひずみ解による 動的ウィンクラばねによる結果の有用性を述べている。 しかし，杭周の動的ウィンクラばねの簡便な評価法にお いて, 静的ウィンクラばね系では高振動数領域での適用 性に問題が残されており，また，静的剛性が零となる動 的平面ひずみ解による動的ウインクラばね ${ }^{14)}$ の低振動数 領域での評価において, Novak ら ${ }^{15)}$ はより厳密な解析 結果による数表または図表から得られる静的剛性で補正 する提案を行っているものの十分とは言えない。

2）統計的評価法は無限要素法による系統的な解析結果 から得られた杭頭での振動特性を主要な解析パラメータ の回帰式として統計的に直接処理する評価法で，一様地 盤中の水平振動する杭に関して, Kuhlemeyer ${ }^{16)}$ は杭先 端の支持条件に影響されない長い杭の杭頭でのコンプラ イアンスに対して, 静的特性を杭と地盤のヤング係数比 のベき関数で, 振動特性を無次元振動数の多項式で評価 し, Dobry ら ${ }^{17}$ は長い杭の杭頭インピーダンスを同様な 回帰式で表現し，地盤反力係数も同様に取扱っている。 水平振動する支持杭の応答に関して, Gazetas ${ }^{18)}$ は 3 種 類の層状地盤に対する杭頭インピーダンスを柔な杭と地 盤のヤング係数のべき関数で表される静的特性で規準化 し, 杭頭での伝達関数を無次元振動数, 杭と地盤のヤン グ係数比のべき関数および杭の長さ径比のべき関数の積 として評価しており，地震観測された建物の応答と比較 し評価式の有用性を示している。これらの評価法は水平 振動する長い（または柔な）杭に対して有用で実用的で はあるが，使用した解析の数值結果および解析パラメー 夕の範囲に左右される傾向にあり，より多くの解析パラ メータに依存する短い（または奧な）浮杭や鉛直（また はロッキング）振動する杭の振動特性の評価にも至って
いない。

本論文は, 文献 19）および 20)，21）の一部を整理し, さらに詳細な検討を加えたものである。ここでは，基盤 上の粘弾性表層地盤中に設置された単杭の鉛直・水平振 動において, 杭一地盤系の基本的な振動特性を簡便に評 価する目的から，多くの解析パラメー夕を容易に導入で きるWinkler タイプ評価法を用いる。この評価法にお いては，動的ウィンクラばねの簡便な評価が重要な課題 となる。これを解決するために本論文では，3 次元全無 限弾性体の内部点加振解である簡便な動的 Kelvin 解を 用い，低振動数領域にも適用でき，地盤の材料特性およ び杭長さ径比に依存する動的ウィンクラばねを誘導し， その評価式が杭と地盤の剛性比に依存する有効杭長・層 厚の概念を導入した簡便な表現で提案される。さらに, 提案する動的ウィンクラばねを用い，杭のせん断変形を 考慮した杭の運動方程式を解くことにより，杭一地盤系 の振動特性を簡易に評価できる手法を示す。広範囲のパ ラメトリックスタディから, 弾性波動論に基づく浮杭一 地盤系の厳密解および他の解析結果との比較によって, 提案する簡易評価法の精度を検証し，地震観測されたあ る杭基礎建物に本簡易評価法を適用しその有用性につい て述べる。

\section{2. 解析モデルとパラメトリックスタディ}

ここで取扱う杭一地盤系の解析モデルは, Fig.1に示 すように浮杭と基盤上にある表層地盤からなる。表層地 盤は履歴型の内部減衰を有する均質等方の 3 次元粘弾性 連続体とし，周辺地盤亡杭下部に位置する杭と同径の土 柱に分けて考える。杭を 1 次元弾性棒またはせん断変形 を考慮した Timoshenko 梁として取扱う。鉛直・水平 調和外乱として杭頭加振力および基盤入力地動を想定す る。

杭は地盤と完全に密着して振動するものとして，その

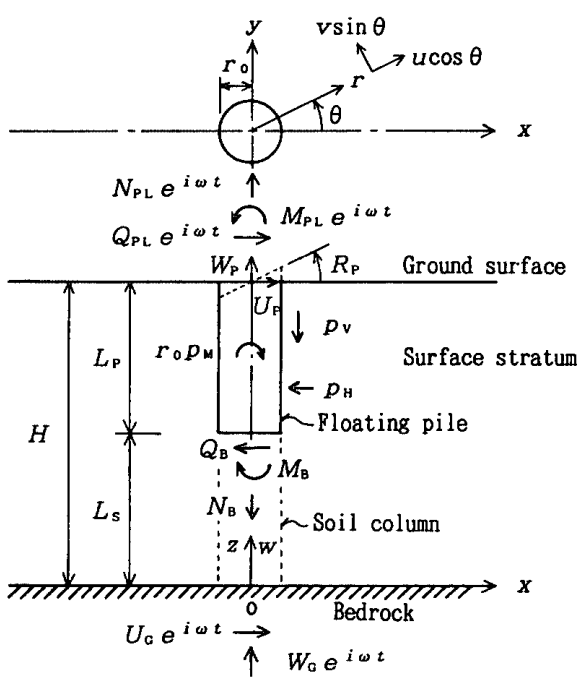

Fig. 1 Model of a soil-pile system 
運動方程式および構成式は， $z$ (鉛直) 方向と $x$ (水平) 方向の絶対変位 $W_{P}, U_{P}$ および回転角 $R_{P}$ によって次式 の上うに表現される。時間因子 $e^{i \omega t}$ は便宣上省略すれ ば,

$$
\begin{aligned}
& \frac{d N_{P}}{d z}-p_{v}=-\rho_{P} A_{P} \omega^{2} W_{P} ; \frac{N_{P}}{E_{P} A_{P}}=\frac{d W_{P}}{d z} \\
& \frac{d Q_{P}}{d z}-p_{H}=-\rho_{P} A_{P} \omega^{2} U_{P} ; \frac{Q_{P}}{x G_{P} A_{P}}=\frac{d U_{P}}{d z}+R_{P} \\
& \frac{d M_{P}}{d z}-Q_{P}-r_{0} p_{M}=-\rho_{P} I_{P} \omega^{2} R_{P} ; \frac{M_{P}}{E_{P} I_{P}}=\frac{d R_{P}}{d z}
\end{aligned} \mid
$$

ここに, $i=$ 虚数単位, $\omega=$ 円振動数, $r_{0}=$ 杭の半径, $\rho_{P}$ $=$ 杭の密度, $E_{P}=$ 杭のヤング係数, $G_{P}=$ 杭のせん断弾 性係数, $x=$ 杭のせん断に対する形状係数, $A_{P}=$ 杭の断 面積, $I_{P}=$ 杭の断面 2 次モーメントで, $N_{P}, Q_{P}, M_{P}$ はそ れぞれ杭の軸方向力, せん断力, 曲げモーメントである。 杭周には地盤の鉛直方向反力 $p_{v}$ ，水平方向反力 $p_{H}$ ，回 転反力 $p_{M}$ が作用し，杭頭には $N_{P L}, Q_{P L}, M_{P L}$ の振幅で 加振され，“基盤入力変位振幅として $W_{G} ， U_{G}$ を想定して いる。また杭先端には土柱の反力として $N_{B}, Q_{B}, M_{B}$ が 作用することになる。

この解析モデルに対して著者らは既に，有限フーリ エ・ハンケル変換法を用いて（1）式の厳密解を定式化 し，積分方程式を用いずに複素連立 1 次方程式によって 混合境界値問題を処理し，地盤の鉛直振動と水平振動の 連成による一般化されたレイリ一波の効果を含んだ解を

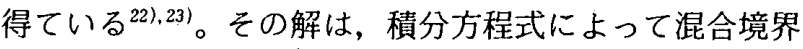
値問題を処理した支持杭に対する厳密解 ${ }^{24)}$.25) と比較して その有効性を確認している。

杭基礎で支持された構造物の地震時における応答を求 める問題を，構造物の慣性力による相互作用（inertial interaction）問題と杭基礎の地動拘束による相互作用 (kinematic interaction) 問題に分けて考えることがで き, 前者は杭頭インピーダンスを, 後者は伝達関数を求 める問題に相当している。つまり，構造物との連成時に 重要な役割を演じる地動入力のない杭頭でのインピーダ ンス $[K]$ および基礎入力地動による自由な杭頭での伝 達関数 $[S]$ は次式によって定義される。

$$
\begin{aligned}
& \left\{\begin{array}{l}
N_{P L} \\
\ddot{Q}_{P L} \\
M_{P L}
\end{array}\right\}=\left[\begin{array}{ccc}
K_{V V}, & 0, & 0 \\
0, & K_{H H}, & K_{H R} \\
0, & K_{R H}, & K_{R R}
\end{array}\right]\left\{\begin{array}{l}
W_{P L} \\
U_{P L} \\
R_{P L}
\end{array}\right\} \\
& \left\{\begin{array}{l}
W_{P L} \\
U_{P L} \\
R_{P L}
\end{array}\right\}=\left[\begin{array}{cc}
S_{V G}, & 0 \\
0, & S_{H G} \\
0, & S_{R G}
\end{array}\right]\left\{\begin{array}{l}
W_{G} \\
U_{G}
\end{array}\right\} \\
& =\left[\begin{array}{cc}
S_{V F}, & 0 \\
0, & S_{H F} \\
0, & S_{R F}
\end{array}\right]\left\{\begin{array}{l}
W_{F} \\
U_{F}
\end{array}\right\}
\end{aligned}
$$

ここで, 相反定理から連成項 $K_{H R}=K_{R H}$ となり, $W_{P L}$, $U_{P L}, R_{P L}$ は杭頭での絶対変位と回転角である。また， (3b) 式で示すように，杭の存在しない表層自由地盤の 地表面での絶対変位応答 $W_{F}, U_{F}$ に対しても表現でき る。 $[K],[S]$ なよ゙の関数は次のように 10 個の解析パ ラメータで構成されれ。

$$
\begin{array}{r}
K \text { or } S=F\left(\frac{L_{P}}{r_{0}}, \frac{L_{S}}{r_{0}}, \frac{V_{P}}{V_{H}}, \frac{A_{P}}{\pi r_{0}^{2}}, \frac{I_{P}}{\pi r_{0}^{4}}, \frac{E_{P}}{\chi G_{P}},\right. \\
\left.\frac{\rho_{P}}{\rho}, \frac{V_{v}}{V_{H}}, \xi, b_{1}\right) \cdots \ldots \ldots \ldots \ldots \ldots \ldots \ldots \ldots \ldots \ldots \ldots \ldots \ldots \ldots
\end{array}
$$

ここに, $L_{P}=$ 杭長, $L_{s}=$ 土柱長; 層厚 $H=L_{P}+L_{s}$ で, 杭の縦波速度 $V_{P}=\sqrt{E_{P} / \rho_{\mathrm{P}}}$, 地盤の横波速度 $V_{H}=\sqrt{\mu / \rho}$, 地盤の縦波と横波の速度比 $V_{V} / V_{H}=\sqrt{2\left(1-\nu_{s}\right) /\left(1-2 \nu_{s}\right)}$ であり， $\mu, \rho, \nu_{s}$ はそれぞれ地盤のせん断弾性係数, 密 度, ポアソン比である。地盤の履歴減衰比 $\xi$ は Lamé の定数の複素表現 $\mu^{*}=\mu(1+2 i \xi), \quad \lambda^{*}=\lambda(1+2 i \xi)$ で 定義され，無次元振動数 $b_{1}=\omega / \omega_{H 1}$ （または層厚に関係 しない $\left.a_{1}=b_{1} r_{0} / H\right)$ で, 表層地盤の基本振動数 $\omega_{H 1}=$ $\pi V_{H} /(2 H)$ で無次元化される。

提案する簡易評価法の精度を検証するために，厳密解 によるパラメトリックスタディを行う。解析パラメータ の範囲として, 表層地盤では軟弱土層を想定し, 縦波と 横波の速度比 $V_{V} / V_{H}=2.0 \sim 5.0\left(\nu_{S}=1 / 3 \sim 0.479\right)$ で, 一般的な $V_{V} / V_{H}=2.5\left(\nu_{s}=0.405\right)$ および履歴減衰比 $\xi$ $=0.05$ を主として用いている。一方，杭では中実な円 形断面の場所打コンクリート杭を想定し，ポアンン比 $\nu_{P}=1 / 6$, 形状係数 $x=6\left(1+\nu_{P}\right) /\left(7+6 \nu_{P}\right)^{26)}$, ヤング係 数 $E_{P}=2.1 \times 10^{5} \mathrm{kgf} / \mathrm{cm}^{2}$ とし, 密度比を一般的な $\rho_{\rho} / \rho$ $=4 / 3$ とする。杭と地盤の剛性比 $E_{P} / \mu$ を反映する杭と 地盤の速度比を $V_{P} / V_{H}=7.5 \sim 960$ とし, 通常の表層地 盤剛性を網羅している。杭長さ径比 $L_{P} / r_{0}=10 \sim 80$, 杭 長と層厚の比 $L_{P} / H=1 \sim 1 / 3$ (または土柱長さ径比 $L_{s} / r_{0}=0 \sim 80 ）$ の範囲を考える。

厳密解の数值解析では, 有限フーリエ・ハンケル逆変 換形としての級数解の項数を鉛直振動では 25 項, 水平 振動では 35 項までとった結果を示す。この数值解析結 果は鉛直, 水平振動共に数％程度の誤差内で収斂する ことを確認している。

\section{3. 杭一地盤系の近似解析}

3.1 動的 Winkler モデルと解析仮定

表層地盤の変位解は，入反射場（上付添字 I）である 基盤入力地動による杭の存在しない自由地盤の変位亡散 乱場 (上付添字 S) である杭周, 杭先端地盤の加振によ る変位の和として表現することができる。つまり，

$$
W=W^{\prime}+W^{s}, U=U^{\prime}+U^{s}, R=R^{\prime}+R^{s}
$$

杭周おょび杭先端（下付添字 B ）に作用する地盤反力 
も変位と同様にそれぞれ重ね合わせて, 次のように表現 できる。

$$
\left.\begin{array}{l}
p_{v}=p_{V}^{I}+p_{V}^{S}, p_{H}=p_{H}^{\prime}+p_{H}^{S}, p_{M}=p_{M}^{\prime}+p_{M}^{S} \\
N_{B}=N_{B}^{I}+N_{B}^{S}, Q_{B}=Q_{B}^{I}+Q_{B}^{S}, M_{B}=M_{B}^{\prime}+M_{B}^{S}
\end{array}\right\}
$$

入反射場における絶対変位, 回転角は次式のようになり, $W^{\prime}=W_{F} \cos x_{V}^{*}(H-z) ; W_{F}=W_{G} / \cos \left(x_{v}^{*} H\right)$ $U^{\prime}=U_{F} \cos x_{H}^{*}(H-z) ; U_{F}=U_{G} / \cos \left(x_{H}^{*} H\right)$ $R^{\prime} \equiv 0$

また，杭周および杭先端に作用する地盤反力は，杭部分 を地盤に置換した 1 次元土柱の運動方程式（1）から容 易に求めることができ，次のようになる。

$$
\left.\begin{array}{l}
p_{\nu}^{l} \equiv 0, p_{H}^{I} \equiv 0, p_{M}^{I}=-Q^{\prime} / r_{0}, M_{B}^{\prime} \equiv 0 \\
N_{B}^{\prime}=E_{v} A_{s} \frac{d W^{I}}{d z}, Q_{B}^{I}=G_{s} A_{s} \frac{d U^{I}}{d z} ; z=L_{s}
\end{array}\right\}
$$

ここに, $E_{v}=\lambda^{*}+2 \mu^{*}, G_{s}=\mu^{*}, A_{s}=\pi r_{0}^{2}$ で, 波数 $x_{v}^{*}$ $=\omega \sqrt{p / E_{v}}, x_{H}^{*}=\omega \sqrt{\rho / G_{s}}$ である。

しかし，散乱場における杭周および杭先端に作用する 地盤反力を, 厳密な解析では杭と地盤の複雑な動的相互 作用により簡単な形で表現することができない。そこで， 簡便な評価を行うために，地盤をWinkler タイプの粘 弾性体モデルとして仮定する。つまり，杭周および杭先 端に作用する地盤反力は，それぞれ杭周および杭先端地 盤の動的ウィンクラばねを用いて次のように定義され る。

$$
\left.\begin{array}{l}
p_{V}^{S}=K_{C V}^{*} W^{S} ; N_{B}^{S}=K_{B V}^{*} W_{B}^{S} \\
p_{H}^{S}=K_{C H}^{*} U^{S} ; Q_{B}^{S}=K_{B H}^{*} U_{B}^{S}
\end{array}\right\}
$$

ここに，添字を $\nu=V, H$ とおき，複素ば丽郕を $K_{c \nu}^{*}$ $=K_{C \nu}(1+2 i \xi), K_{B \nu}^{*}=K_{B \nu}(1+2 i \xi)$ で近似し, $K_{C \nu}$, $K_{B \nu}$ は弾性体の動的ウインクラばね剛性とする。

さらに，近似解析において，次の仮定を設ける。

1) $L_{P} / r_{0} \geqq 20$ の杭においては, 杭頭インピーダンスに 及ぼす杭周地盤の回転反力の影響は比較的小さく ${ }^{211}$ ，ま た浮杭先端はヒンジの状態に近いので, $p_{M}^{S}=0, M_{\mathrm{B}}^{S}=0$ として無視する。ただし， $p_{M}^{\prime} \neq 0$ は取り入れる。

2）ここで取扱う振動数範囲において杭の回転慣性力に よる影響は小さいので，これを考慮しない。

3）杭周地盤の動的ウィンクラばねは深さ方向に関して 一定とする。

4)支持杭先端の境界条件 ${ }^{33}$ は, 良質な支持層に杭の直径 程度の根入れがあるとしてピン支持とする。

\section{2 杭頭インピーダンスおよび伝達関数}

杭周地盤と杭との変位の連続条件 : $W_{P}=W, U_{P}=U$, $R_{\mathrm{P}}=R$ および前節の（5) （9）式を考慮して杭の運 動方程式（1）を解くことにより，杭の変位および応力 が得られる。解析パラメー夕を次のように表現すること
にする。

$$
\begin{aligned}
& \alpha=\sqrt{\frac{K_{C V}^{*}}{E_{P} A_{P}}}, \beta=\sqrt[4]{\frac{K_{C H}^{*}}{4 E_{P} I_{P}}}, \zeta=\lambda_{H}^{2} \frac{E_{P} I_{P}}{\chi G_{P} A_{P}}, \\
& \eta_{V}=\lambda_{V} \frac{E_{P} A_{P}}{K_{B V}^{*}}, \eta_{H}=2 \lambda_{H}^{3} \frac{E_{P} I_{P}}{K_{B H}^{*}}
\end{aligned}
$$

ここに, 波数を $x_{P}=\omega / V_{P}, x_{b}=\sqrt[4]{x_{P}^{2} A_{P} / I_{P}}$ とおけば, 杭 の特性パラメータが次のように決定される。

$$
\left.\begin{array}{l}
\lambda_{V}=\alpha \sqrt{1-x_{P}^{2} / \alpha^{2}} ; \operatorname{Re}\left(\lambda_{V}\right) \geqq 0 \\
\lambda_{H}=\beta \cdot \sqrt[4]{1-\chi_{b}^{4} /\left(4 \beta^{4}\right)} ; \operatorname{Re}\left(\lambda_{H}\right) \geqq 0
\end{array}\right\}
$$

したがって,杭頭インピーダンスは次のように得られる。

$$
\left.\begin{array}{c}
K_{V V}=\lambda_{v} E_{P} A_{P} \cdot \frac{D_{V V}}{D_{V K}}, K_{H H}=4 \lambda_{H}^{3} E_{P} I_{P} \cdot \frac{D_{H H}}{D_{H K}} \\
K_{H R}=2 \lambda_{H}^{2} E_{P} I_{P} \cdot \frac{D_{H R}}{D_{H K}}, K_{R R}=2 \lambda_{H} E_{P} I_{P} \cdot \frac{D_{R R}}{D_{H K}}
\end{array}\right\}
$$

ここに, $\lambda_{1}=\lambda_{H} \sqrt{1+\zeta}, \quad \lambda_{2}=\lambda_{H} \sqrt{1-\zeta}$ として, $C_{h}=$ $\cosh \left(2 \lambda_{1} L_{P}\right), \quad S_{h}=\sinh \left(2 \lambda_{1} L_{P}\right) / \sqrt{1+\zeta}, \quad C_{0}=\cos (2$ $\left.\lambda_{2} L_{P}\right), \quad S_{i}=\sin \left(2 \lambda_{2} L_{P}\right) / \sqrt{1-\zeta}$ とおけば,

$$
\left.\begin{array}{rl}
D_{V V}= & 1+\eta_{V} \cdot \tanh \left(\lambda_{V} L_{P}\right) \\
D_{V K}= & \eta_{V}+\tanh \left(\lambda_{V} L_{P}\right) \\
D_{H H}= & {\left[C_{h}+C_{0}\right]+\eta_{H}\left[S_{h}+S_{i}\right]} \\
D_{H R}= & {\left[S_{h}+S_{i}\right]+\eta_{H}\left[\frac{C_{h}}{1+\zeta}-\frac{C_{0}}{1-\zeta}+\frac{2 \zeta}{1-\zeta^{2}}\right]} \\
D_{R R}= & {\left[C_{h}-C_{0}\right]+\eta_{H}\left[S_{h}-S_{i}\right]} \\
D_{H K}= & {\left[(1+2 \zeta) S_{h}-(1-2 \zeta) S_{i}\right]} \\
& +\eta_{H}\left[\frac{1+2 \zeta}{1+\zeta} C_{h}+\frac{1-2 \zeta}{1-\zeta} C_{0}+\frac{2}{1-\zeta^{2}}\right]
\end{array}\right\}
$$

支持杭の場合には $\eta_{V}, \eta_{H} \rightarrow 0$ とおくことにより得られ る。また, 杭のせん断変形が無視できる場合には $\zeta \rightarrow 0$ とすればよく，一般に行われている弾性支承梁の曲げ理 論解に相当する結果が得られる。

さらに, 杭の特性パラメータ $\lambda_{V} L_{P}, \lambda_{H} L_{P}$ に関して (13) 式を関数近似することにより，杭頭インピーダンスが次 のような簡易な形で表現される。

1) 剛短杭

[浮杭 : $\left.\left|\lambda_{v} L_{P}\right| \leqq 0.3,\left|\lambda_{H} L_{P}\right| \leqq 0.5\right]$

$$
\left.\begin{array}{l}
K_{V V}=K_{B V}^{*}+K_{D V}^{*}, K_{H H}=K_{B H}^{*}+K_{D H}^{*} \\
K_{H R}=\left(K_{B H}^{*}+\frac{1}{2} K_{D H}^{*}\right) L_{P}, K_{R R}=\left(K_{B H}^{*}+\frac{1}{3} K_{D H}^{*}\right) L_{P}^{2}
\end{array}\right\}
$$

[支持杭 : $\left.\left|\lambda_{V} L_{P}\right|,\left|\lambda_{H} L_{P}\right| \leqq 1\right]$

$$
\left.\begin{array}{l}
K_{V V}=K_{P V}+\frac{1}{3} K_{D V}^{*}, K_{H H}=K_{P H}+\frac{1}{2} K_{D H}^{*} \\
K_{H R}=\left(K_{P H}+\frac{1}{10} K_{D H}^{*}\right) L_{P}, K_{R R}=\left(K_{P H}+\frac{1}{30} K_{D H}^{*}\right) L_{P}^{2}
\end{array}\right\}
$$

ここに, $K_{P V}=E_{P} A_{P} / L_{P}, K_{P H}=3 E_{P} I_{P} / L_{P}^{3}$ は地盤の存在 
しない自立杭の杭頭インピーダンスである。 $K_{D v}^{*}=\left(K_{c v}^{*}\right.$ $\left.-\rho_{P} A_{P} \omega^{2}\right) L_{P}, K_{D H}^{*}=\left(K_{C H}^{*}-\rho_{P} A_{P} \omega^{2}\right) L_{P}$ は総杭周動的ばね 剛性で, 杭頭インピーダンスへのその奇与は浮杭に比べ 支持杭ではかなり小さくなっている。

2) 柔長杭

[浮杭，支持杭 $: \operatorname{Re}\left(\lambda_{V} L_{P}\right), \operatorname{Re}\left(\lambda_{H} L_{P}\right) \geqq 3$ ]

$$
\left.\begin{array}{l}
K_{v V}=\lambda_{v} E_{P} A_{P}, K_{H H}=\frac{4}{1+2 \zeta} \lambda_{H}^{3} E_{P} I_{P} \\
K_{H R}=\frac{2}{1+2 \zeta} \lambda_{H}^{2} E_{P} I_{P}, K_{R R}=\frac{2}{1+2 \zeta} \lambda_{H} E_{P} I_{P}
\end{array}\right\}
$$

静的問題では, 杭の特性パラメータは $\xi=0$ とすれば,

$$
\alpha_{0}=\sqrt{K_{C V} /\left(E_{P} A_{P}\right)}, \beta_{0}=\sqrt[4]{K_{C H} /\left(4 E_{P} I_{P}\right)} \cdots
$$

になり，文献 3）に示されるものに対応する。また，柔 長杭 (long-flexible pile) は杭の水平抵抗に関して慣用 として分類されている「長い杭」 $\left(\beta_{0} L_{P} \geqq 3\right)^{2), 3}$ に相当す るが，(15）式はさらに鉛直問題および杭のせん断変形 を考慮した動的表現になっている。この杭の限界長さを 次のように定義する。

$$
L_{c}=3 / \alpha_{0} \text { または } L_{c}=3 / \beta_{0} \text {. }
$$

この限界長さより短いものが杭の水平抵抗に関して慣用 として分類されている「短い杭」であるが, 剛短杭 (short-rigid pile) および剛短杭と柔長杭の間にある中 間杭 (intermediate pile) がこれに相当している。この ように杭の特性を 3 種に分類してとらえることができ， $\alpha_{0} L_{P}, \beta_{0} L_{P}$ が杭の挙動を把握する上で重要な特性パラ メータとなる。

一方, 自由な杭頭での伝達関数は，(3b) 式の表胃で 示せば次のように得られる。

$$
\begin{gathered}
S_{V F}=a_{V}+\frac{1}{D_{V S}} b_{V} T_{B V} \\
\left\{\begin{array}{c}
S_{H F} \\
S_{R F}
\end{array}\right\}=\left\{\begin{array}{c}
a_{H} \\
0
\end{array}\right\}+\frac{1}{D_{H S}}\left[\begin{array}{lll}
D_{H 1}, & D_{H 2}, & D_{H 3} \\
D_{R 1}, & D_{R 2}, & D_{R 3}
\end{array}\right]\left\{\begin{array}{c}
b_{R} \\
b_{H} T_{B H} \\
b_{R} T_{B H}
\end{array}\right\}
\end{gathered}
$$

ここに,

$$
\begin{aligned}
& a_{V}=\frac{\alpha^{2}}{\lambda_{V}^{2}+x_{V}^{* 2}} \\
& a_{H}=\frac{1}{D_{H 0}}\left[4 \beta^{4}\left(1+\zeta \frac{x_{H}^{* 2}}{\lambda_{H}^{2}}\right)-x_{H}^{* 2} \frac{G_{S} A_{S}}{E_{P} I_{P}}\right] \\
& a_{R}=-\frac{1}{D_{H 0}}\left[4 \beta^{4}-\left(x_{H}^{* 2}+4 \zeta \lambda_{H}^{2}\right) \frac{G_{S} A_{S}}{E_{P} I_{P}}\right] \\
& D_{H 0}=4 \lambda_{H}^{4}+4 \zeta \lambda_{H}^{2} x_{H}^{* 2}+x_{H}^{* 4} \\
& b_{V}=1-a_{V}+\frac{\eta_{V}}{\lambda_{V}}\left(a_{V}-\frac{E_{V} A_{S}}{E_{P} A_{P}}\right) x_{V}^{*} \tan \left(x_{V}^{*} L_{P}\right) \\
& b_{H}=1-a_{H}-\frac{\eta_{H}}{2 \lambda_{H}^{3}} a_{R} x_{H}^{* 3} \tan \left(x_{H}^{*} L_{P}\right) \\
& b_{R}=-\frac{1}{2 \lambda_{H}^{2}} a_{R} x_{H}^{* 2}
\end{aligned}
$$

$$
\begin{aligned}
T_{B V}= & \frac{\cos \left(x_{V}^{*} L_{P}\right)}{\cosh \left(\lambda_{v} L_{P}\right)}, \\
T_{B H}= & \frac{\cos \left(x_{H}^{*} L_{P}\right)}{2 \cosh \left(\lambda_{1} L_{P}\right) \cos \left(\lambda_{2} L_{P}\right)} \\
D_{V S}= & D_{V v} \\
D_{H S}= & {\left[S_{h}-S_{i}\right]+\eta_{H}\left[\frac{C_{h}}{1+\zeta}+\frac{C_{0}}{1-\zeta}-\frac{2}{1-\zeta^{2}}\right] } \\
D_{H 1}= & D_{H R} \\
D_{H 2}= & S_{h}\left(C_{0}+1\right)-S_{i}\left(C_{h}+1\right) \\
D_{H 3}= & -\left[S_{h}\left(C_{0}+1\right)+S_{i}\left(C_{h}+1\right)+2 \eta_{H} S_{h} S_{i}\right] \\
D_{R 1}= & -2 \lambda_{H} D_{H H} \\
D_{R 2}= & 2 \lambda_{H} S_{h} S_{i} \\
D_{R 3}= & 2 \lambda_{H}\left\{\left(\left(C_{h}+1\right)\left(C_{0}+1\right)+\zeta S_{h} S_{i}\right]\right. \\
& \left.+\eta_{H}\left[S_{h}\left(C_{0}+1\right)+S_{i}\left(C_{h}+1\right)\right]\right\} \cdots \cdots \cdots . . .
\end{aligned}
$$

ここに， $a_{V}, a_{H}, a_{R}$ は $K_{C V}^{*} W^{\prime}, K_{C H}^{*} U^{\prime}, p_{M}^{L}$ による特殊解 で， $b_{v}, b_{H}, b_{R}$ の項は杭頭と杭先端の境界条件を満たす 余解である。剛短杭では杭先端の影響により余解の項に よる効果が現れるが，柔長杭では杭先端からの影響（係 数 $\left.T_{B V}, T_{B H}\right)$ が小さくなるため，次のような簡単な形で 表現でき，杭長，層厚に依存しなくなる。

$$
S_{V F}=a_{v}, S_{H F}=a_{H}+b_{R}, S_{R F}=-2 \lambda_{1} b_{R}
$$

\section{4. 動的ウィンクラばねの簡易評価}

\section{1 杭先端地盤のウインクラばね}

杭先端地盤の静的なウィンクラばねは，剛基礎上にあ る表層地盤地表面の剛円形基礎に対する Kausel の静的

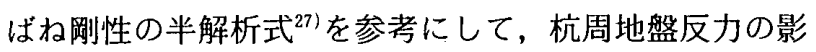
響による低減効果を考虑した補正（鉛直： $5 / 8$ 倍, 水平 : $6 / 8$ 倍程度）を行った次式によって簡易評価される。

$$
\begin{aligned}
& {\left[L_{S} / r_{0} \geqq 5, L_{P} / r_{0} \geqq 10\right]} \\
& K_{B V}=\frac{2.56 \mu r_{0}}{1-\nu_{S}}\left(1+\frac{2 r_{0}}{L_{S}}\right), K_{B H}=\frac{6 \mu r_{0}}{2-\nu_{S}}
\end{aligned}
$$

提案する簡易式 (21) の精度を検証するために, 剛短杭 における $L_{s}$ と $\nu_{S}$ に対して，厳密解 $\left(K_{B v} ; b_{1}=0.5\right.$, $V_{P} / V_{H}=60, L_{P} / r_{0}=10,20, K_{B H} ; b_{1}=0.2, V_{P} / V_{H}=960$, $\left.L_{P} / r_{0}=10\right)$ による剛性および Butterfield $ら^{6)}$ の静的解 $\left(V_{P} \rightarrow \infty, L_{P} / r_{0}=10,20\right)$ 加ら得られる剛性との比較 をFig. 2 に示す。この図から，(21）式の評価は $K_{B V}$, $K_{B H}$ 共に $10 \%$ 程度の誤差を有しているが, $N_{B} / N_{P L}=$ $0.18\left(L_{P} / r_{0}=10\right), 0.12\left(L_{P} / r_{0}=20\right), Q_{B} / Q_{P L}=0.19$ $\left(U_{P L}=0\right), 0.09\left(R_{P L}=0\right)$ を考慮すれば，杭頭インピー ダンスへのその誤差による影響ばわずかである。

杭先端地盤の動的なウィシクラばねにおいて，ここで 取扱う振動数範囲では，その実部で表される剛性はあま り振動数に依存せずほぼ一定值で, 虚部で表される減衰 は振動数に比例する逸散減衰を示す傾向にあるが28), 杭 頭インピーダンスの簡便な評価において, 杭先端地盤反 力の及ぼす影響は比較的小さいので, ここでは杭先端地 


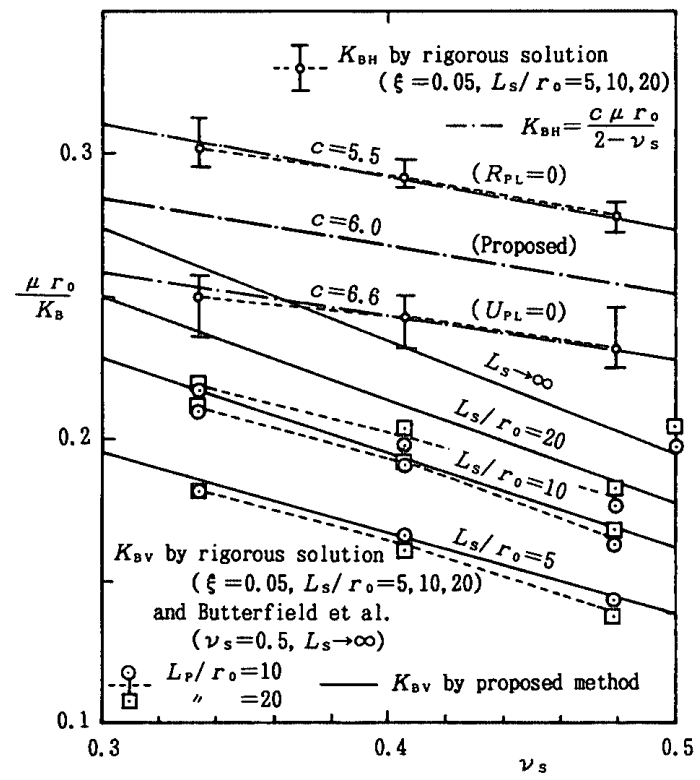

Fig. 2 Comparison of stiffnesses at pile tip by proposed method with those by rigorous and other solutions in static case

盤の動的ウィンクラばねを静的ウィンクラばねで評価す ることにする。

\section{2 杭周地盤のウィンクラばね}

杭周地盤の動的なウィンクラばねの評価は杭頭イン ピーダンスに大きな影響を及ぼす重要な因子であり，物 理的に評価することにする。鉛直・水平振動において， 動的 Kelvin 解に鏡像の方法 ${ }^{29}$ を適用し, 半無限弾性体 の内部点加振の近似解として応用する。半無限地盤中の 仮想的な浮杭の軸 $(r=0)$ に沿って, Fig. 3 に示すよ うに, 三角形分布（杭頭で 1 , 杭先端で 0 となる直線分 布)と一様分布する 2 種類の分布加振力を仮定し, 鉛直 水平方向の動的ウィンクラばねを杭周 $\left(r=r_{0}\right)$ におい て次式で定義する。

$$
\left.\begin{array}{l}
K_{C V}=2 \pi r_{0} k_{V} ; k_{V}=-\tau / W \\
K_{C H}=\pi r_{0} k_{H} ; k_{H}=-\sigma / U
\end{array}\right\}
$$

ここに, $\tau, \sigma$ は $z, x$ 方向杭周表面力である。 $k_{H}$ を誘 導するにあたり, 分布加振解 ${ }^{21)}$ に動的平面ひずみ解を重
ね合わせることにより，杭周地盤の円形保持の仮定を地 表面付近で近似的に満足させ，さらに一様分布加振では 杭先端に点加振力を作用させることにより解の改善を 図っている。三角形分布加振解（下付添字 1) および一 様分布加振解（下付添字 2) の 1 例を無次元振動数 $a_{0}$ $\left(=\frac{\pi}{2} a_{1}\right)=0.01,0.5$ に対して Fig. 3 に示す。ここに, $U=(u-v) / 2, \quad V=(u+v) / 2$ で, $u, v$ は Fig. 1 で定 義された $r, \theta$ 方向の地盤変位であり, 地表面での杭周 表面力 $\tau_{0 \nu}, \sigma_{0 \nu}(\nu=1,2)$ で規準化している。この図から, 杭周の動的ウィンクラばね係数 $k_{V}, k_{H}$ は, 杭長に沿っ て変化するもののほぼ一様に分布し, 地表面での値が代 表的な值を示しており， $a_{0}=0.5$ と言った高振動数では

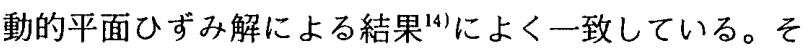
こで, 杭周地盤の動的ウィンクラばねを深さ方向に関し て一定値とし, その値を地表面での值で評価することに する。

分布加振解の地表面での值は， $L_{P} / r_{0} \geqq 10$ に対する関 数近似を行うことによって,次のように簡易表現される。 1）三角形分布加振解 [低域近似： $\left.a_{P} \leqq 2\right]$

$$
\begin{aligned}
& \frac{W_{1}}{A_{1} r_{0}}=-\left[\ln \left(\frac{2 L_{P}}{r_{0}}\right)-\frac{1}{4\left(1-\nu_{S}\right)}-1\right] \\
&+\frac{1}{24} a_{P}^{2}+\frac{1}{3} i a_{P}\left(1-\frac{1}{60} a_{P}^{2}\right) \\
& \frac{U_{1}}{B_{1} r_{0}}=-\frac{3-4 \nu_{s}}{8\left(1-\nu_{S}\right)}\left[\ln \left(\frac{2 L_{P}}{r_{0}}\right)+\frac{1}{2\left(3-4 \nu_{S}\right)}-1\right] \\
&+\frac{1}{32} a_{P}^{2}\left(1-\frac{1}{36} a_{P}^{2}\right)+\frac{1}{6} i a_{P}\left(1-\frac{1}{30} a_{P}^{2}\right) \\
& \frac{\tau_{1}}{A_{1} \mu}=1-\frac{3-2 \nu_{s}}{2\left(1-\nu_{S}\right)} \cdot \frac{r_{0}}{L_{P}} \\
& \frac{\sigma_{1}}{B_{1} \mu}=1-\frac{3-4 \nu_{s}}{4\left(1-\nu_{S}\right)} \cdot \frac{r_{0}}{L_{P}}
\end{aligned}
$$

[高域近似 : $\left.a_{p}>2\right]$

$$
\frac{W_{1}}{A_{1} r_{0}}=\frac{W_{0}}{r_{0}}+\frac{1}{a_{P}^{2}}\left\{e^{-i b_{P}}\right.
$$

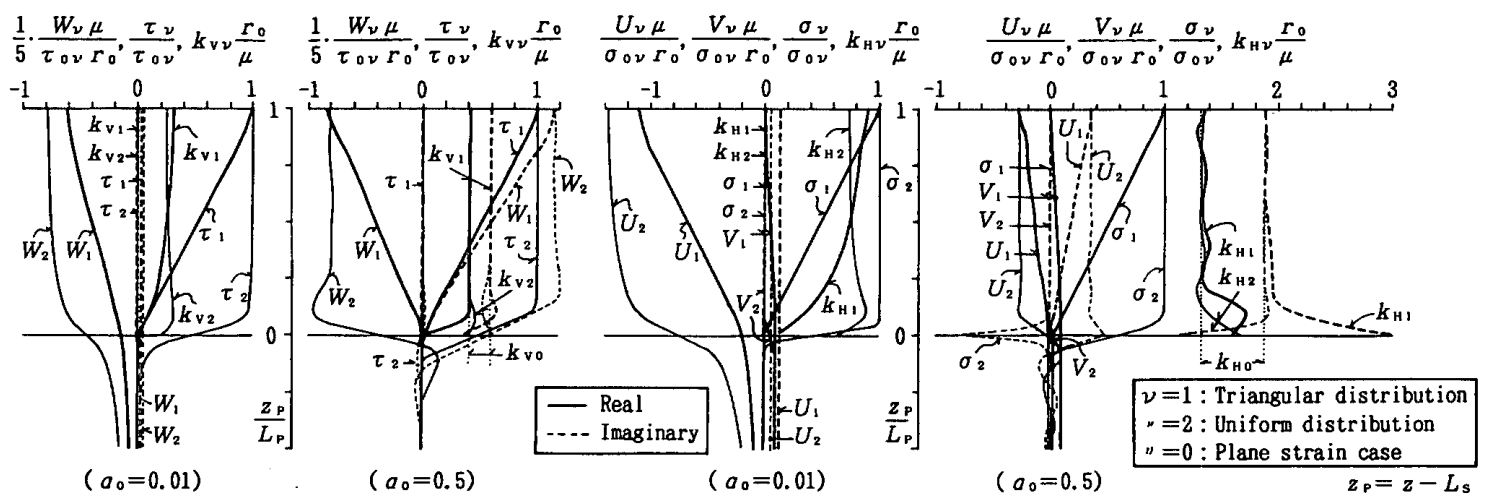

a) Vertical vibration

b) Horizontal vibration

Fig. 3 Distribution of displacements and stresses on pile circumference by approximate solutions along depth $\left(V_{v} / V_{H}=2.5, \xi=0.05, L_{P} / r_{0}=40, L_{s} \rightarrow \infty\right)$ 


$$
\left.\begin{array}{rl} 
& \left.+\frac{L_{P}}{r_{0}}\left[\left(1-i a_{0}\right) e^{-i a_{0}}-e^{-i b_{0}}\right]\right\} \\
\frac{U_{1}}{B_{1} r_{0}}= & \frac{U_{0}}{r_{0}}+\frac{1}{4 a_{P}^{2}}\left\{2 e^{-i a_{P}}\right. \\
& \left.-\frac{L_{P}}{r_{0}}\left[\left(1+i a_{0}\right) e^{-i a_{0}}-\left(1-i b_{0}\right) e^{-i b_{0}}\right]\right\} \\
\frac{\tau_{1}}{A_{1} \mu}= & \frac{\tau_{0}}{\mu}-\frac{r_{0}}{L_{P}} e^{-i a_{0}}-\frac{2}{a_{P}^{2}} \cdot \frac{L_{P}}{r_{0}}\left[\left(1+i a_{0}\right) e^{-i a_{0}}\right. \\
& \left.-\left(1+i b_{0}\right) e^{-i b_{0}}\right] \\
\frac{\sigma_{1}}{B_{1} \mu}= & \frac{\sigma_{0}}{\mu}-\frac{r_{0}}{2 L_{P}}\left[e^{-i a_{0}}+e^{-i b_{0}}\right] \\
& +\frac{1}{a_{P}^{2}} \cdot \frac{L_{P}}{r_{0}}\left[\left(1+i a_{0}\right) e^{-i a_{0}}\right. \\
& \left.-\left(1+i b_{0}\right) e^{-i b_{0}}\right]
\end{array}\right\}
$$

2）一様分布加振解

[低域近似： $\left.a_{P} \leqq 2\right]$

$$
\begin{aligned}
\frac{W_{2}}{A_{2} r_{0}}= & -\left[\ln \left(\frac{2 L_{P}}{r_{0}}\right)-\frac{1}{4\left(1-\nu_{S}\right)}\right] \\
& +\frac{1}{8} a_{P}^{2}+\frac{2}{3} i a_{P}\left(1-\frac{1}{30} a_{P}^{2}\right) \\
\frac{U_{2}}{B_{2} r_{0}}= & -\frac{3-4 \nu_{S}}{8\left(1-\nu_{S}\right)}\left[\ln \left(\frac{2 L_{P}}{r_{0}}\right)+\frac{1}{2\left(3-4 \nu_{S}\right)}\right] \\
& +\frac{3}{32} a_{P}^{2}\left(1-\frac{5}{108} a_{P}^{2}\right) \\
& +\frac{1}{3} i a_{P}\left(1-\frac{1}{15} a_{P}^{2}\right) \\
\frac{\tau_{2}}{A_{2} \mu}= & 1, \frac{\sigma_{2}}{B_{2} \mu}=1
\end{aligned}
$$

[高域近似： $a_{P}>2$ ]

$$
\begin{aligned}
\frac{W_{2}}{A_{2} r_{0}}= & \frac{W_{0}}{r_{0}}+\frac{1}{a_{P}^{2}}\left[2 e^{-i a_{P}}-\left(1+i b_{P}\right) e^{-i b_{P}}\right] \\
\frac{U_{2}}{B_{2} r_{0}}= & \frac{U_{0}}{r_{0}}+\frac{1}{2 a_{P}^{2}}\left\{e^{-i b_{P}}-2 i e^{-i a_{P}}\right. \\
& -\frac{i}{a_{P}}\left(1-\frac{2}{a_{P}}\right)\left[\left(1+i a_{P}\right) e^{-i a_{P}}\right. \\
& \left.\left.-\left(1+i b_{P}\right) e^{-i b_{P}}\right]\right\} \\
\frac{\tau_{2}}{A_{2} \mu}= & \frac{\tau_{0}}{\mu}, \frac{\sigma_{2}}{B_{2} \mu}=\frac{\sigma_{0}}{\mu}
\end{aligned}
$$

$(24 \mathrm{~b})$

3）動的平面ひずみ解

$$
\begin{aligned}
\frac{W_{0}}{r_{0}}= & \frac{\pi}{2} i H_{0}^{(2)}\left(a_{0}\right), \frac{\tau_{0}}{\mu}=-\frac{\pi}{2} i a_{0} H_{1}^{(2)}\left(a_{0}\right) \\
\frac{U_{0}}{r_{0}}= & \frac{\pi^{2}}{32} b_{0}^{2}\left[H_{2}^{(2)}\left(b_{0}\right) H_{0}^{(2)} \cdot\left(a_{0}\right)\right. \\
& \left.+H_{2}^{(2)}\left(a_{0}\right) H_{0}^{(2)}\left(b_{0}\right)\right] \\
\frac{\sigma_{0}}{\mu}= & -\frac{\pi^{2}}{16} b_{0}^{2} a_{0}\left[H_{2}^{(2)}\left(b_{0}\right) H_{1}^{(2)}\left(a_{0}\right)\right.
\end{aligned}
$$

$$
\left.+\frac{x_{H}}{x_{V}} H_{2}^{(2)}\left(a_{0}\right) H_{1}^{(2)}\left(b_{0}\right)\right]
$$

ここに; $A_{1}, A_{2}, B_{1}, B_{2}$ は任意定数で, 波数 $x_{H}=\omega / V_{H}$, $x_{V}=\omega / V_{V}$ で, $a_{0}=x_{H} r_{0}, b_{0}=x_{V} r_{0}, \quad a_{P}=x_{H} L_{P}, \quad b_{P}=$ $x_{v} L_{P}$ で, $H_{\nu}^{(2)}$ は $\nu$ 次の第 2 種 Hankel 関数である。 $L_{P}$ $\rightarrow \infty$ とすれば, (23b)， (24b) 式の結果は高振動数領 域において有効性のある動的平面ひずみ解（25）式によ る結果 ${ }^{14)}$ に一致することが分かる。

分布加振解による杭周地盤の静的なウィンクラばね係 数と箃密解および他の静的解析から得られる結果との比 較を Fig. 4 に示す。厳密解による結果は，杭頭インピー ダンス $\left(\xi=0.05\right.$, 鉛直振動： $K_{v v}, b_{1}=0.5$, 水平振動 $\left.\therefore K_{\text {Hн }}, b_{1}=0.2\right)$ の㧩性を用い, 静的状態とした（12） 式から逆算した等価なウィンクラばね係数であり, 浮杭 における杭先端地盤のウィンクラばねには（21）式を用 いている。一方，半無限地盤中の浮杭に関する Butterfield $\zeta^{6)}$, Banerjee $\check{\zeta}^{7)}$, Poulos $\zeta^{8)}$, Randolph $ら^{91} お$ よび柔長杭に関する Kuhlemeyer ${ }^{16)}$, Dobry ら ${ }^{17)}$, Gazetas ${ }^{18)}$ の解析結果から同様に $K_{B H}=0$ として逆算したもの を, $V_{P} / V_{H}\left(\rho_{\mathrm{P}} / \rho=4 / 3\right)$ に対して示す。柔長杭では $V_{P} / V_{H}$ に対応した杭長として限界長さ $L_{c}$ (Gazetas の 結果では文献 18）による有効杭長）を用いている。

この図から，三角形分布または一様分布加振による静 的ウィンクラばね係数の評価には, 支持杭 $\left(L_{s}=0\right)$ の 場合または浮杭 $\left(L_{s} \neq 0\right)$ が剛で半無限地盤中 $\left(L_{s} \rightarrow \infty\right)$ にある場合にそれぞれよく一致する結果が見られる。三 角形分布加振の場合では一様分布加振の場合より静的 ウィンクラばね係数が大きくなっており，これを $L_{s}$ (ま たは層厚 $H ）$ による効果として評価することができる。 柔長杭において, 三角形分布加振による評価が支持杭の 場合の静的ウィンクラばね係数を小さく見積る傾向にあ るが, 杭長 $L_{P}$ を限界長さ $L_{c}$ で評価 ( $L_{0}$ 評価) するこ とにより破線で示すようによい結果が得られ，同様に柔 長な浮杭の場合に対しても三角形分布加振による評価が 適合することが分かる。

また，この図には鉛直問題で柔長でない杭に有効性の ある Randolph らの簡易式9)（付録 A.1）による結果を 点線で示している。この簡易式は一様分布加振解による 結果とよい対応を示している。

以上の考察から, 鉛直・水平振動に関する表層地盤中 の浮杭の場合を含む動的ウィンクラばね係数の一般化さ れた一簡易評価法として,

1）柔長杭の支持杭的な評価：

有効杭長 $L_{0}=\min \left(L_{P}, L_{C}\right)$

有効層厚 $H_{0}=\min \left(H, L_{c}\right)$

2）支持杭および半無限地盤中の浮杭に対する分布加振 解による評価の適合性： 

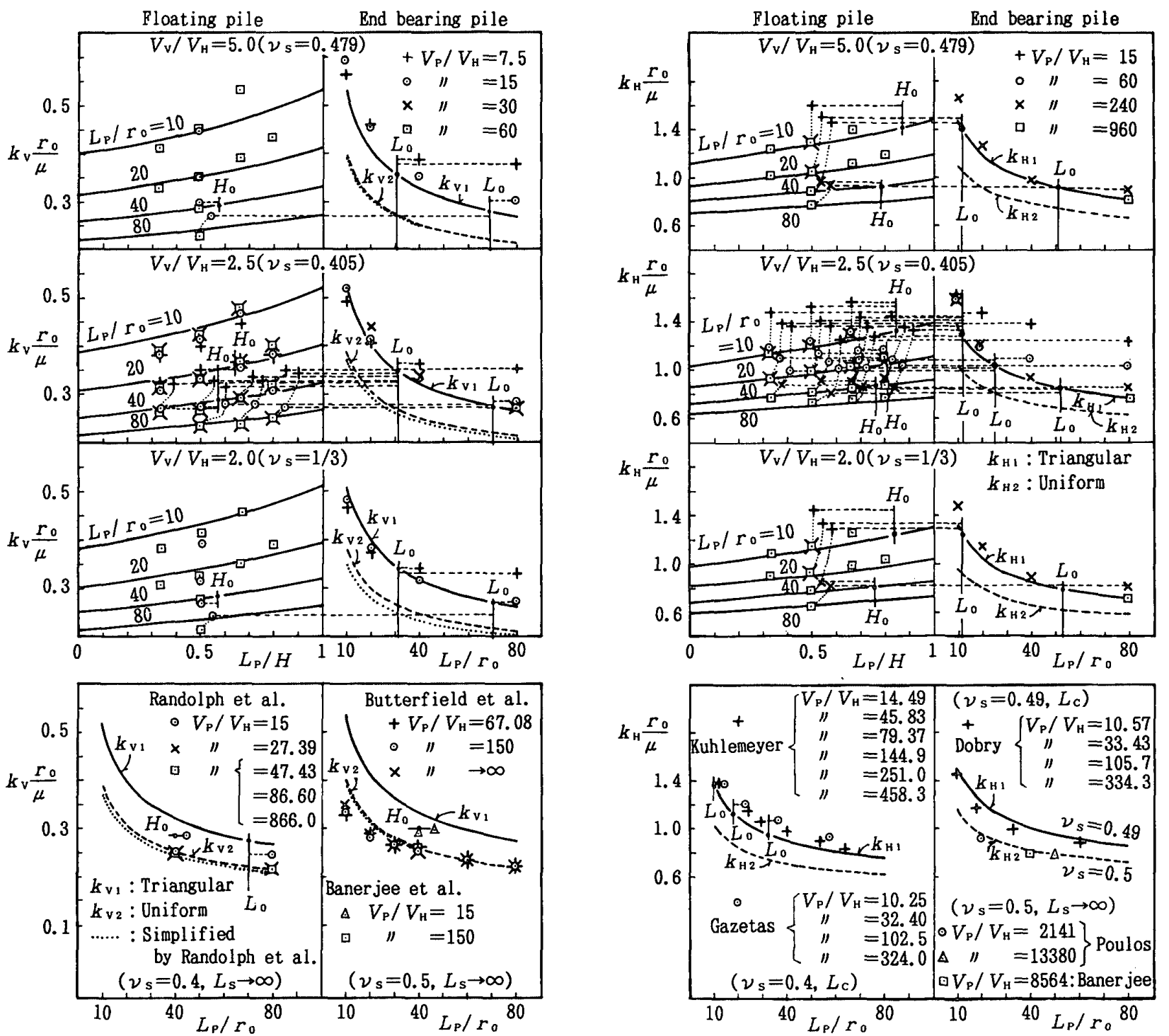

Fig. 4 Comparison of stiffness coefficients on pile circumference by proposed method with those by rigorous and other solutions in static case

$$
A_{1}=B_{1}=L_{0} / H_{0}, A_{2}=B_{2}=1-L_{0} / H_{0}
$$

を導入することにより， $L_{\mathrm{P}}$ を $L_{0}$ で置換した分布加振解

（23），(24）式の重放合わせから物理的に得られる次式 を提案する。

$\left[L_{0} / r_{0} \geqq 10\right]$

$$
k_{v}=\frac{\tau_{1}+\tau_{2}}{W_{1}+W_{2}} ; k_{H}=-\frac{\sigma_{1}+\sigma_{2}}{U_{1}+U_{2}}
$$

（28）式による静的ウインクラば係数の簡易評価式は, 次のように簡単な表現として得られる。

$$
\begin{aligned}
\frac{1}{k_{V}}= & \frac{r_{0}}{\mu}\left[\ln \left(\frac{2 L_{0}}{r_{0}}\right)-\frac{1}{4\left(1-\nu_{s}\right)}-\frac{L_{0}}{H_{0}}\right] \\
& /\left[1-\frac{3-2 \nu_{s}}{2\left(1-\nu_{s}\right)} \cdot \frac{r_{0}}{H_{0}}\right] \\
\frac{1}{k_{H}}= & \frac{r_{0}}{\mu} \cdot \frac{3-4 \nu_{s}}{8\left(1-\nu_{S}\right)}\left[\ln \left(\frac{2 L_{0}}{r_{0}}\right)\right. \\
& \left.+\frac{1}{2\left(3-4 \nu_{s}\right)}-\frac{L_{0}}{H_{0}}\right]
\end{aligned}
$$

$$
/\left[1-\frac{3-4 \nu_{s}}{4\left(1-\nu_{s}\right)} \cdot \frac{r_{0}}{H_{0}}\right] \quad \quad \quad
$$

杭の限界長さ $L_{c}$ は支持杭の静的ウインクラばね係数 $\left(H=L_{P}=L_{C}\right)$ の評価式 (29) を用い，(17) 式の数回 の反復試行により精度よく求まるが, 次の回帰式を提示 しておく。

$$
\frac{L_{c}}{r_{0}}=\frac{5}{2}\left[\frac{E_{P} A_{P}}{\mu A_{s}}\right]^{\frac{7}{12}}: \text { 鉛直, } \frac{36}{11}\left[\frac{E_{P} I_{P}}{E_{S} I_{S}}\right]^{\frac{13}{18}}: \text { 水平 }
$$

ここに, $E_{s}=$ 地盤のヤング係数, $I_{s}=\pi r_{0}^{4} / 4$ である。(30) 式の簡易式は $\nu_{s} \geqq 0.3$ に対して，鉛直問題では $\pm 2 \%$

$\left(E_{\mathrm{P}} A_{\mathrm{P}} / \mu A_{s}=35 \sim 750\right)$, 水平問題では $\pm 1 \%\left(E_{\mathrm{P}} I_{P} / E_{s} I_{S}\right.$ =15１0000）の誤差内に納まっている。

また，（30）式を（17）式に代入すれば，柔長杭に対 する静的ウィンクラばね係数が次のように得られる。 

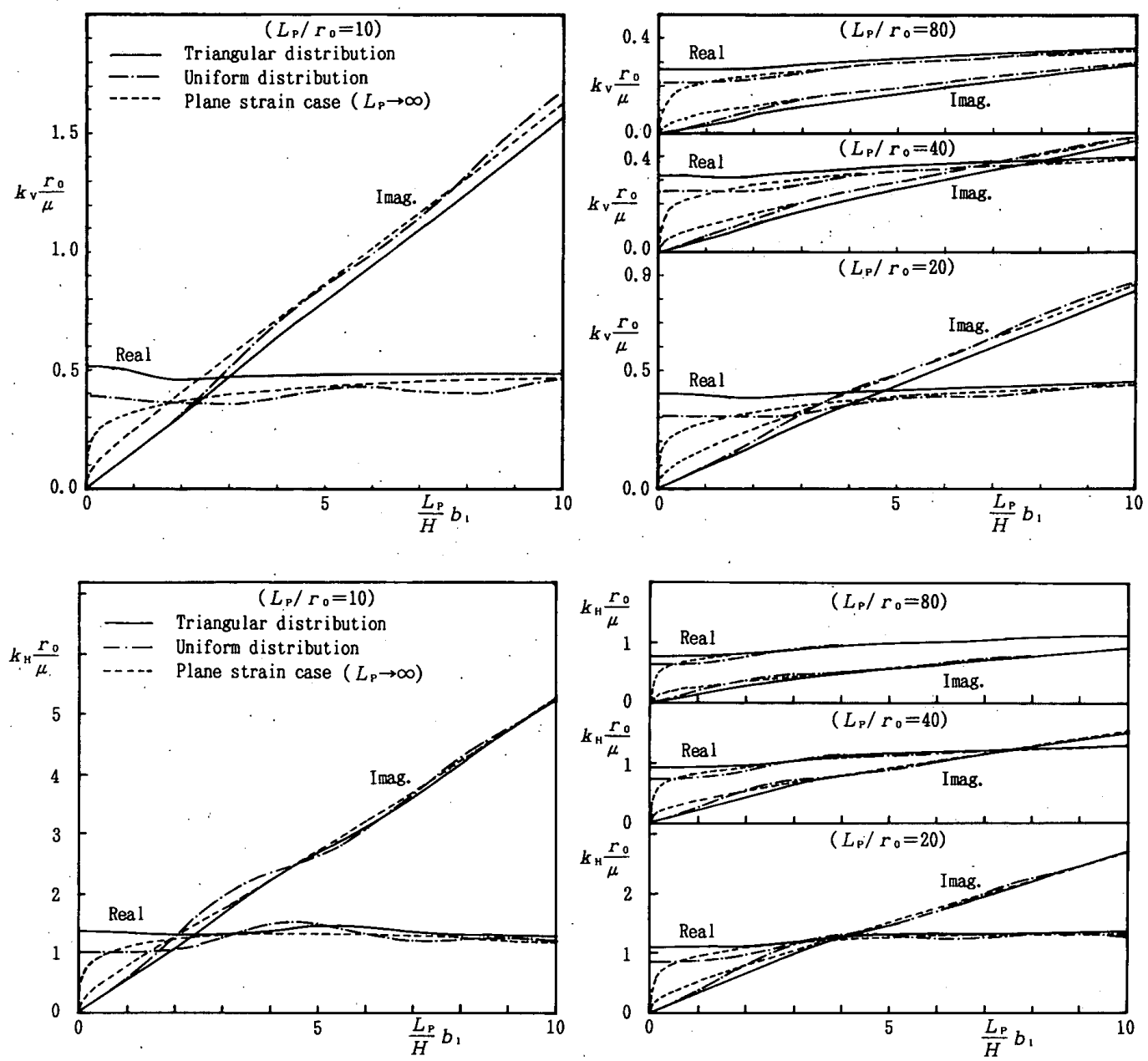

Fig. 5 Variation of complex stiffness coefficients on pile circumference due to three excitations with frequency $\left(V_{v} / V_{H}=2.5, \xi=0\right)$

$$
k_{v} \frac{r_{0}}{\mu}=\frac{18}{25} \cdot \sqrt[6]{\frac{\mu A_{S}}{E_{P} A_{P}}}, k_{H} \frac{r_{0}}{E_{S}}=\left[\frac{11}{12}\right] \cdot \sqrt[12]{\frac{E_{S} I_{S}}{E_{P} I_{P}}}
$$

(31) 式の簡易式には $k_{v}, k_{H}$ 共に $\pm 4 \%$ 内の誤差がある。 提案するこの簡易式は, 水平問題の柔で長い杭に有効な Francis の簡易式 ${ }^{5}$ (付録 A.2) と $\nu_{s}=0.5$ においてほ とんど一致した表現（差異 $0.5 \%$ ）となうている。

一方，表層地盤中の浮杭の場合に対する (29) 式の簡 易評価と厳密解による結果の比較もまた Fig. 4 に示さ れている。この図から， $L_{0} / H_{0}$ に対する関数の連続性お よび $H_{0}$ 評価を考慮した (29) 式の結果が妥当であるこ とが分かる。この静的な簡易評価法は, $L_{0} / r_{0}=10$ と言っ た非常に短い杭を除けば $k_{V}, k_{H}$ 共に $10 \%$ 程度の誤差 に納まっており，実用上十分な精度を有し有用であると 言える。

鉛直・水平振動における三角形分布, 一様分布加振解 および動的平面ひずみ解 ${ }^{14}$ による動的ウィンク.ラばね係 数の振動数に対する変化を $L_{P} / r_{0}$ とともに Fig. 5 に示 す。

この図から，三角形分布と一様分布加振解による結果 は，低振動数領域では実部がほぼ一定の剛性を表してい
るが，動的平面ひずみ解による結果では実部が静的にな るとともに零に近づく傾向を示す。また，虚部は振動数 とともにほぼ直線的に増加する逸散減衰を表している。 実部，虚部共に高振動数になると一様分布の場合にはわ ずかな変化が現れるが，細長い杭になるほど三者の結果 はほとんど一致するようになる。

このように，(28）式で提案された杭周地盤のウィン クラばね係数 $k_{v}, k_{H}$ の簡易評価法は, 静的・動的問題 に対して既往の簡易評価法 ${ }^{51,9), 14)}$ ともそれぞれよく対応 しており，さらに柔長杭の特性を表す杭と地盤の剛性比 に依存した $L_{0}$ 評価および杭長と層厚の比 $L_{0} / H_{0}$ による 効果 $\left(H_{0}\right.$ 評価 $)$ が考慮され，柔長杭はもとより表層地 盤中の柔長でない支持杭，浮杭にも適用可能で，より一 般化された一簡易評価法として位置づけられる。

\section{5. 単杭の振動特性の簡易評価}

杭頭インピーダンスおよび伝達関数などの振動特性 を，3，4節から簡易に評価することができる。ここでは 提案する単杭の振動特性の簡易評価法の精度の検証を行 う。 

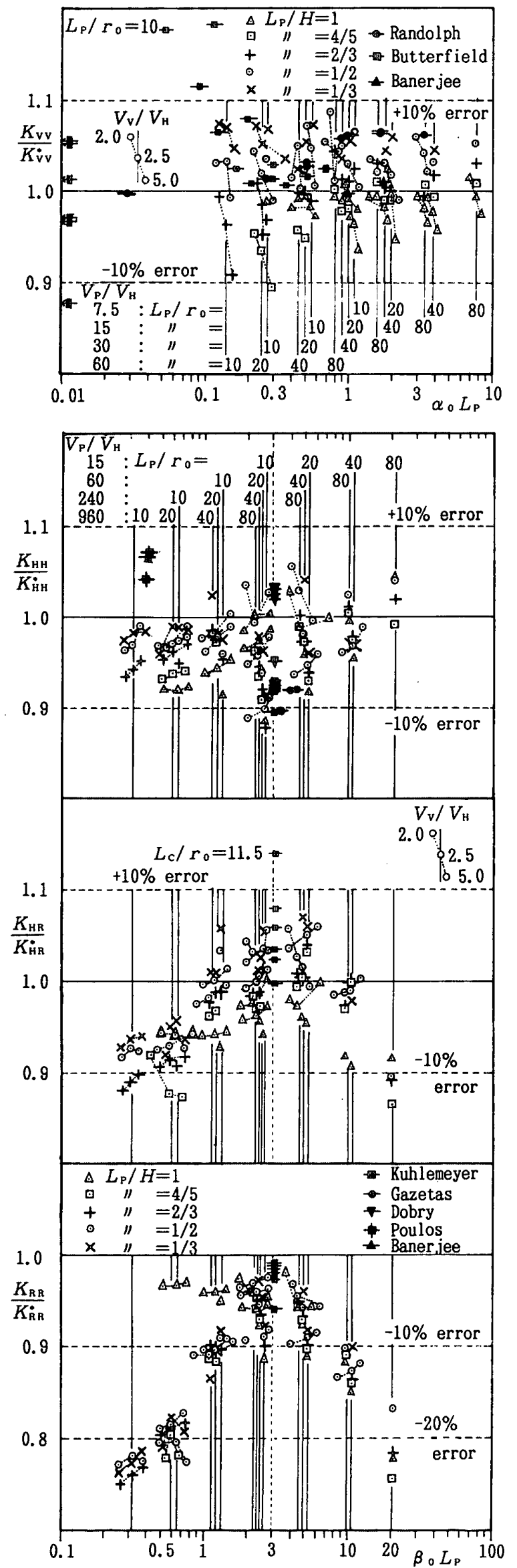

Fig. 6 Comparison of stiffnesses at pile head by proposed method with those by rigorous and other solutions in static case

\section{1 杭頭インピーダンス}

静的な杭頭インピーダンスの剛性に対して，簡易評価 法と添字*で表示した厳密解および他の解析結果との比 較を杭の特性パラメー夕 $\alpha_{0} L_{P}, \beta_{0} L_{P}$ とともに Fig. 6 に 示す。解析パラメー夕はFig. 4 で用いたものに対応す る。

この図から，KVV の簡易評価は，Butterfield らによる $L_{P} / r_{0}=10$ の剛短杭の結果を除き $\pm 10 \%$ 程度の誤差に 納まることが分かる。 $K_{H H}$ の簡易評価は，柔長杭に近い $\beta_{0} L_{P}=3$ 付近の $L_{P} / r_{0}=10$ に対して若干精度が悪くなる ものの, $\pm 10 \%$ 程度の誤差に納まっている。 $K_{H R}$ の簡 易評価では, $\beta_{0} L_{P}=0.5$ 程度以下にある $L_{P} / r_{0}=10,20$ の剛短な浮杭および Kuhlemeyer による $V_{P} / V_{H}=14.49$ $\left(L_{c} / r_{0}=11.5\right)$ に対して精度の悪いものが見られ, $K_{R R}$ の簡易評価では，全般的に過小評価の傾向にあり， 剛短杭の $L_{P} / r_{0}=10,20$ においてその傾向が顕著であ る。この原因は，本簡易評価法には杭周地盤の回転反力 の影響を無視したために生じたももので，回転に関する $K_{R R}$ に特に大きな影響を及ぼしたものであると考えられ る $^{21) 。 ま た ， ~} L_{P} / r_{0}=80$ における $\beta_{0} L_{P}=20$ と言った非 常に柔長な杭に対しても， $K_{H R}, K_{R R}$ 共に過小評価となっ ているが，これは厳密解の数值解析精度に依存するもの とみられ， $L_{0} / H \leqq 11.6 / 80$ といった非常に小さい部分

(有効杭長) にわたる実質的なフーリ工級数の項数が不 十分となり，回転に関するインピーダンスに顕著に現れ たためと考えられる。よって，K $K_{\text {HR }}$ は $10 \%$ 程度の誤 差にあり， $K_{R R}$ においても剛短杭を除けば $10 \%$ 程度の 誤差にとどまっている。

以上から，提案する静的な杭頭インピーダンスの簡易 評価法は，おおむね $\pm 10 \%$ 程度の誤差に納まっており， 実用上十分な精度を有し有用なものとなる。

柔長杭における静的な杭頭インピーダンスの簡易式 は, (31)式の静的ウィンクラばね係数を考慮すれば,(15) 式から次のように得られる。

$$
\begin{aligned}
& \frac{K_{v v}}{\mu r_{0}}=\frac{6}{5} \pi\left[\frac{E_{P} A_{P}}{\mu A_{S}}\right]^{\frac{5}{12}}, \frac{K_{H H}}{E_{S} r_{0}}=\left[\frac{11}{12}\right]^{3} \pi\left[\frac{E_{P} I_{P}}{E_{S} I_{S}}\right]^{\frac{3}{16}} \\
& \frac{K_{H R}}{E_{S} r_{0}^{2}}=\left[\frac{11}{12}\right]^{2} \frac{\pi}{2}\left[\frac{E_{P} A_{P}}{E_{S} A_{S}}\right]^{\frac{11}{24}}, \frac{K_{R R}}{E_{S} r_{0}^{3}}=\frac{11}{24} \pi\left[\frac{E_{P} I_{P}}{E_{S} I_{S}}\right]^{\frac{35}{18}}
\end{aligned}
$$

ただし， $\zeta=\xi=0$ としている。(32) 式の簡易表現は水 平問題における Gazetas ${ }^{18)}$ などによる統計的評価法でよ く用いられる表現形式に相当している。

動的な杭頭インピーダンスの簡易評価法と厳密解によ る解析効果との比較を, 無次元振動数 $a_{1}\left(b_{1}\right)$ とともに Fig. 7 に示す。ここで，文献 21)，28）でも考察してい るように，杭頭インピーダンスに及ぼす $V_{v} / V_{H}=2.0$, $2.5,5.0\left(\nu_{s}=1 / 3,0.405,0.479\right.$ : 以下に示す振動数 はそれぞれこれに対応している) による影響は，厳密解 

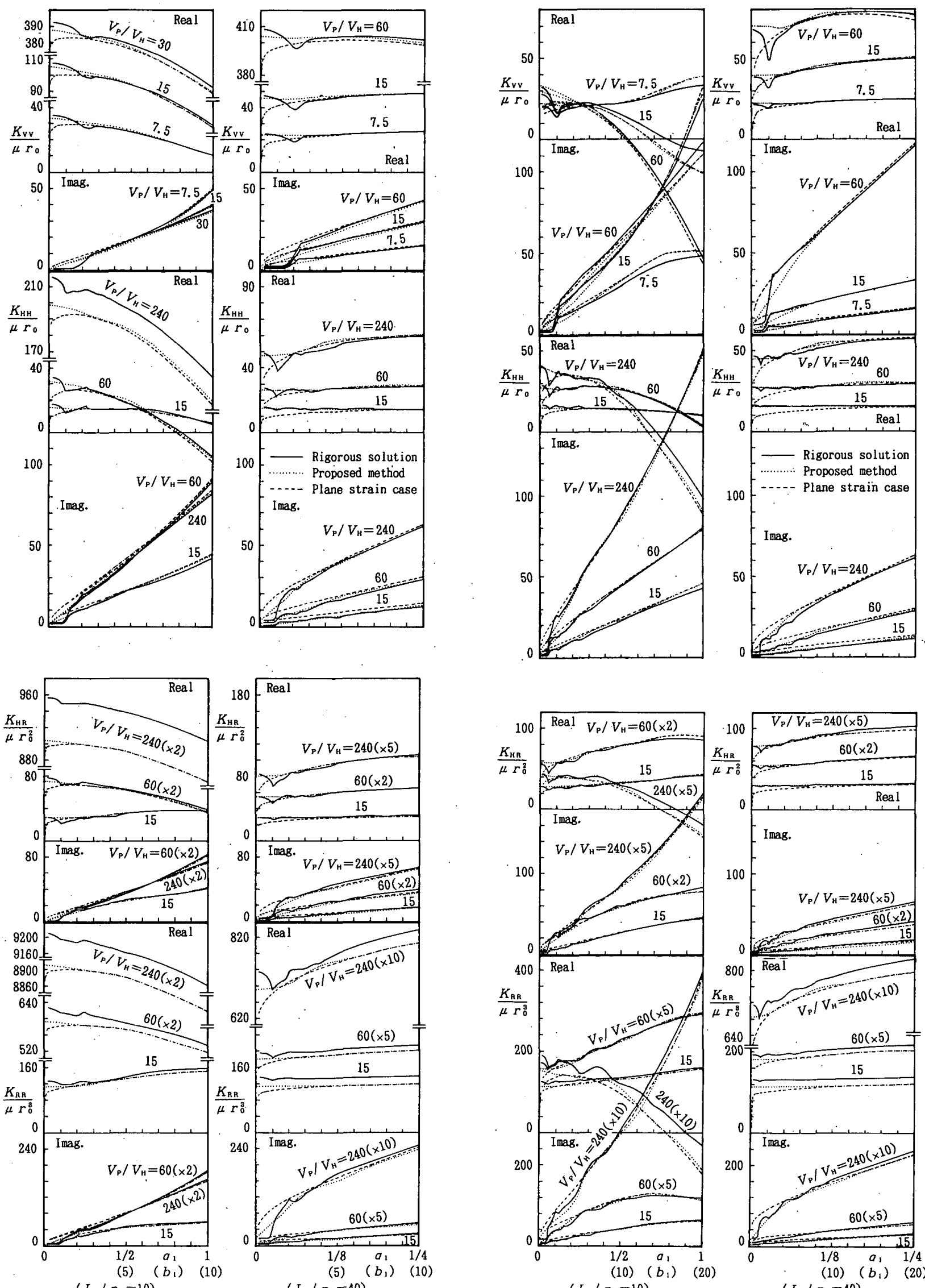

a) End bearing pile $\left(L_{P} / H=1\right)$

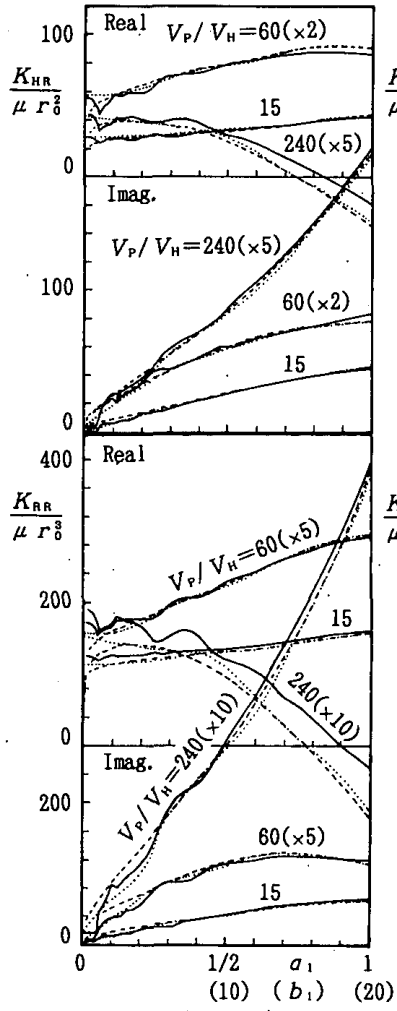

$\left(L_{\mathrm{P}} / r_{0}=10\right)$
b) Floating pile $\left(L_{P} / H=1 / 2\right)$

Fig. 7 Comparison of pile head impedances by proposed method with those by rigorous and plane strain solutions in frequency domain $\left(V_{v} / V_{H}=2.5, \xi=0.05\right)$ 

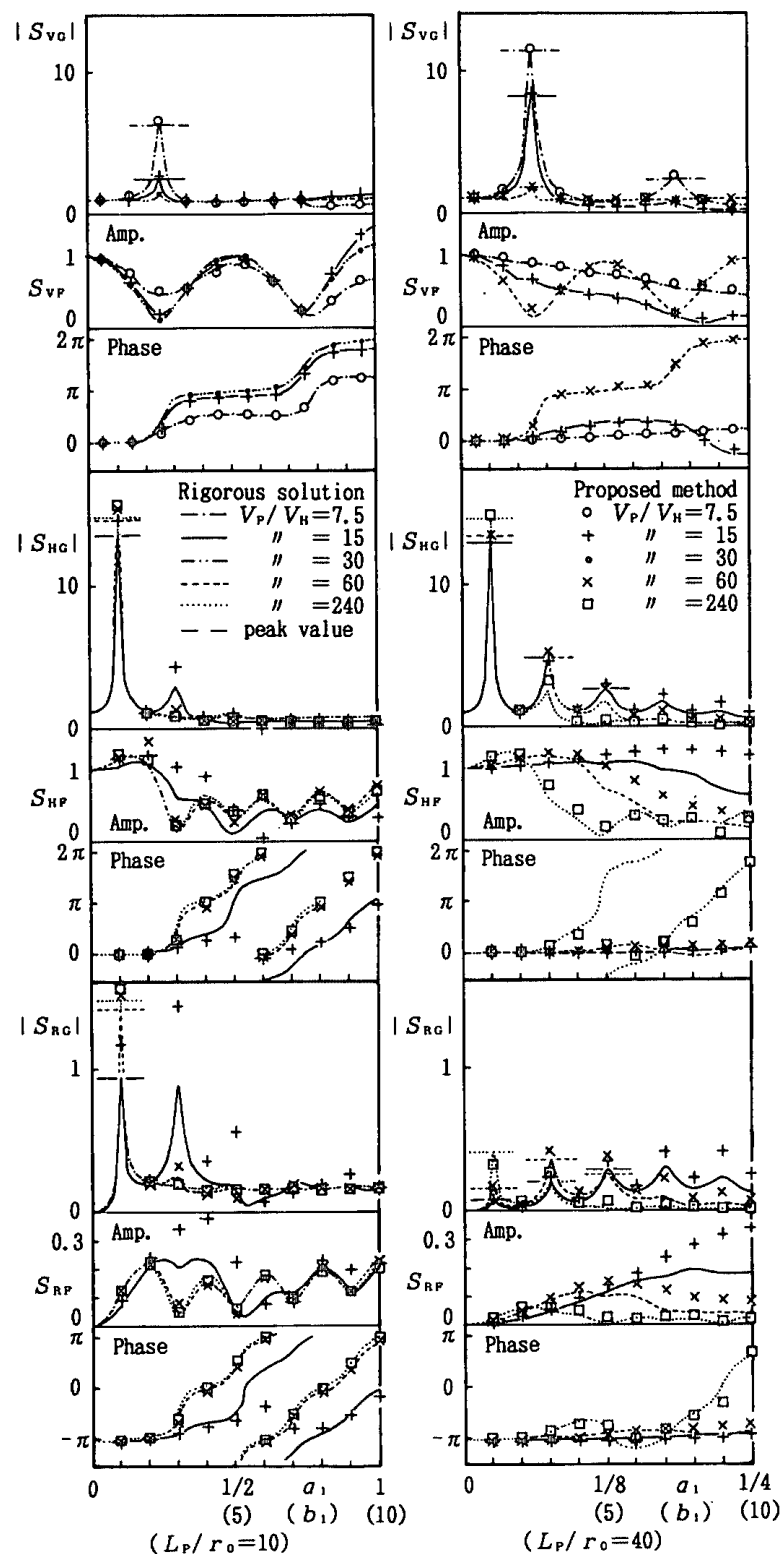

a) End bearing pile $\left(L_{P} / H=1\right)$
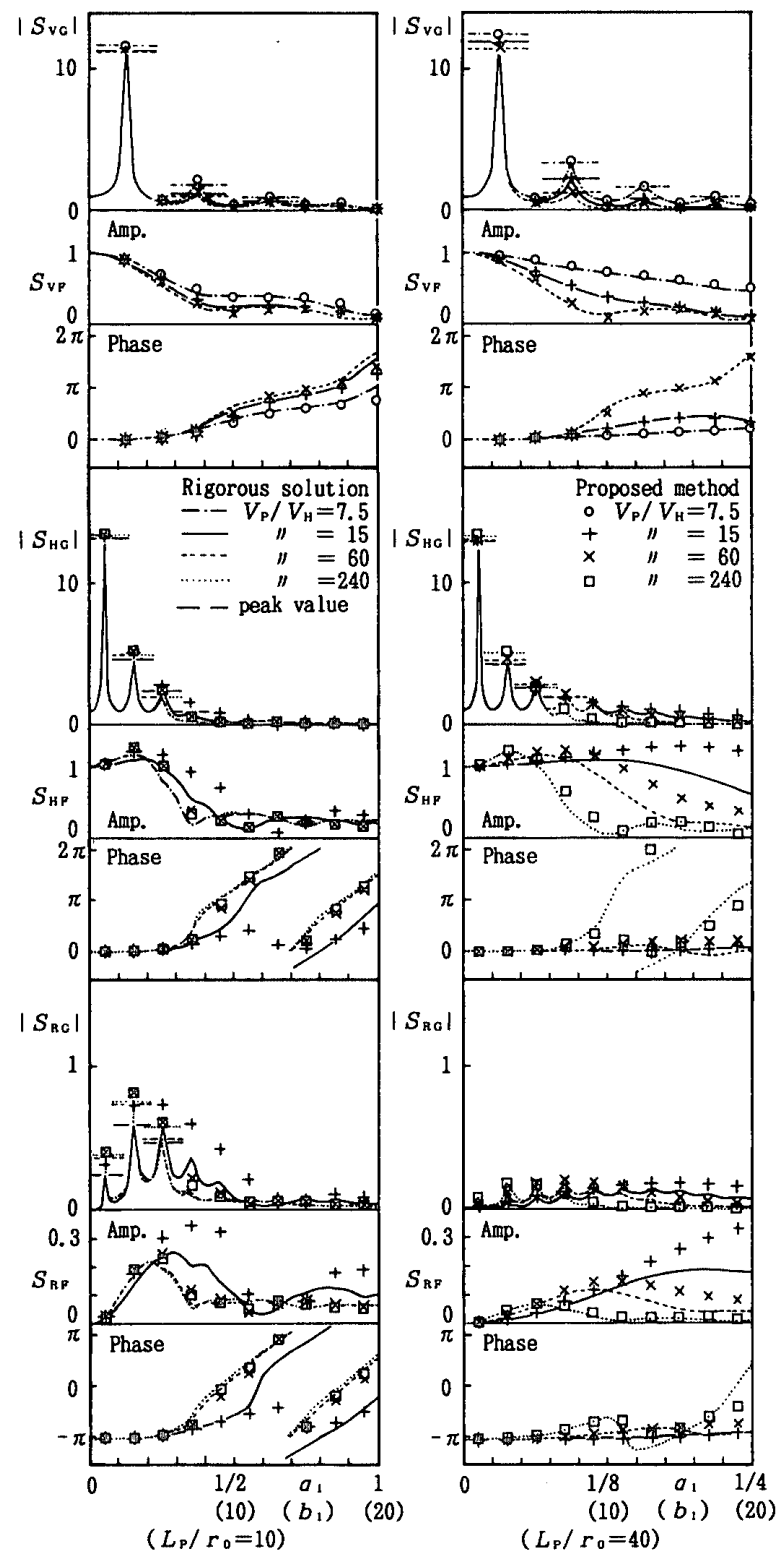

b) Floating pile $\left(L_{\mathrm{P}} / H=1 / 2\right)$

Fig. 8 Comparison of pile head receptances by proposed method with those by rigorous solution in frequency domain $\left(V_{V} / V_{H}=2.5, \xi=0.05\right)$

の表面波による共振点 $\left(b_{1}=1.95,2.31,2.81\right)$ および 群速度の極小点 (Airy 相 $: b_{1}=1.88,1.98,2.07$ ) 付 近までの比較的低い振動数範囲に現れ，高振動数領域で は少なくなる。また， $L_{P} / H$ による効果もこれらの振動 数を超える高振動数範囲では小さく, $L_{P} / H=4 / 5,2 / 3$, $1 / 3$ の結果は $1 / 2$ の結果とよく似た傾向を示す。した がって, Fig. 7 には代表的な $V_{v} / V_{H}=2.5\left(\nu_{S}=0.405\right)$; $L_{P} / H=1,1 / 2 ; L_{P} / r_{0}=10,40$ における結果のみを示

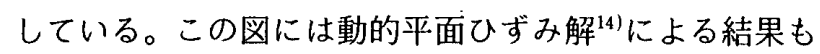
示している。図中に示す $(\times n)$ は実際の值が図中の值 の $n$ 倍であることを表す。

この図から，提案する簡易評価法による結果は，厳密 解における表層地盤の 1 次共振点（水平振動： $b_{1}=1.0$ ) および Airy 相（鉛直振動： $b_{1}=1.98 ）$ 付近の急激に変
化する部分を除けば，全般的に厳密解による結果によく 近似しており, 複雑な動的特性が評価できているのが分 かる。しかし， $K_{R R}$ の実部には静的な場合と同様に精度 の悪化が見られるものの, 虚部では比較的よい結果が得 られ，杭周地盤の回転反力の無視による影響が少ないこ とが分かる。一方, 動的平面ひずみ解による評価には, 高振動数領域では剛短杭になるほど精度のよい結果が得 られるが, 杭が柔長になるとその精度は本簡易評価法に 比べあまりよくなく，また振動数が低くなるとともに用 いることができなくなることが分かる。

以上から，提案する動的な杭頭インピーダンスの簡易 評価法は, 表層地盤の 1 次共振点および Airy 相付近を 除いて，実用上十分な精度を有しており有用なものとな り，既往の動的平面ひずみ解による評価法 ${ }^{(4)}$ を柔長杭お 
よび低振動数領域まで適用可能にした一簡易評価法とし て位置づけられる。

\section{2 伝達関数}

杭頭での伝達関数の簡易評価法と厳密解による解析結 果との比較を杭頭インピーダンスと同様に無次元振動数 $a_{1}\left(b_{1}\right)$ とともに Fig. 8 に示す。

この図から,提案する簡易評価法による結果において, $\left|S_{v G}\right|$ ( $S_{v F}$ の振幅と位相) の評価は支持杭，浮杭共に 非常に精度がよく, $V_{P} / V_{H}$ の変化に対して，支持杭で は杭先端拘束の効果が，浮杭では地動拘束の効果がよく 表現できており，|$S_{V F} \mid<1$ となる入力損失の現象が現 れている。 $\left|S_{H C}\right|$ （ $S_{H F}$ の振幅亡位相）においても，支 持杭，浮杭共によい結果が得られ，また， $b_{1}$ および $V_{\mathrm{P}} / V_{\mathrm{H}}$ の増加とともに入力損失の現象 $\left(\left|S_{H F}\right|<1\right)$ が 見られるものの，低振動数領域では逆に入力の増幅 $\left(\left|S_{H F}\right|>1\right)$ が起こっているのが分かる18)。しかし，杭 が柔で長くなると $S_{H F}$ の振幅では振動数の増加とともに 過大評価になっており，これは本簡易評価法では杭周地 盤の回転反力を無視したために生じたものである。一方， $\left|S_{R G}\right|$ （ $S_{R F}$ の振幅と位相）においても，支持杭，浮杭 共によい結果がみられるものの， $S_{H F}$ の振幅と同じ原因 から柔で長い杭ほぼ高振動数領域でかなり過大評価する 傾向にある。位相特性から， $S_{H F}$ と $S_{R F}$ はほぼ逆位相の 関係にあることが分かる。

以上から，提案する伝達関数の簡易評価法は，柔で長 い杭の $S_{H G}, S_{R G}$ において高振動数になる之精度が悪く なるものの， $S_{V G} ， S_{H G}, S_{R G}$ において実用上十分な精度 を有し有用なものとなる。

\section{6. 本簡易評価法の適用例}

本簡易評価法の有用性を検討するために，Fig. 9 に示 すような入力データがよく整備された地震観測の行われ たある杭基礎(場所打ちコンクリートのベノト杭)建物 ${ }^{301}$ に本簡易評価法を適用する。適用にあたって，次のよう
な処理を行う。

1） GL- $44.6 \mathrm{~m}$ を支持層の支持杭 $\left(L_{P}=43.2 \mathrm{~m}\right)$ とする。 2）基礎スラブ, 基礎梁は剛とし，それによる根入れ部 分 $(\mathrm{GL} \sim \mathrm{GL}-1.4 \mathrm{~m})$ の影響は小さいとして無視する。

3）自由地盤応答および群杭基礎の伝達関数の評価で は，全層（GL－GL-44.6m）にわたって平均化された 次の值を有する一様地盤とみなし，単杭におけるものを 用いる。

$$
\begin{aligned}
& V_{H}=164 \mathrm{~m} / \mathrm{sec}, \rho=1.74 \mathrm{~g} / \mathrm{cm}^{3} ; \mu=478 \mathrm{kgf} / \mathrm{cm}^{2} \\
& \nu_{S}=0.483
\end{aligned}
$$

4）杭頭インピーダンスの評価では，杭の変位分布を考 虑して，有効杭長 $L_{0}$ にわたる三角形分布の重み付け平 均値を採用する。

鉛直振動： $L_{c}=107 r_{0}=53.5 \sim 58.9 \mathrm{~m} ; L_{0}=43.2 \mathrm{~m}$

$$
\mu=487 \mathrm{kgf} / \mathrm{cm}^{2}, \rho=1.74 \mathrm{~g} / \mathrm{cm}^{3}, \nu_{s}=0.482
$$

水平振動： $L_{c}=11.7 r_{0}=5.9 \sim 6.4 \mathrm{~m} \fallingdotseq 6.2 \mathrm{~m}$

$$
\text { ; } L_{0}=6.2 \mathrm{~m}
$$

$E_{s}=2690 \mathrm{kgf} / \mathrm{cm}^{2}, \rho=1.93 \mathrm{~g} / \mathrm{cm}^{3}, \quad \nu_{s}=0.466$

5）群杭基礎のインピーダンス $K_{H H}^{G}, K_{H R}^{G}, K_{R R}^{G}$ は既知の 単杭の杭頭インピーダンスを利用して群杭のインピーダ ンスを求める Dobry らによる簡易法 ${ }^{31} に$ に，本簡易評価 法から得られる単杭の杭頭インピーダンスを用いて評価 される。ただし，群杭の回転ば将 $K_{R R}^{G}=K_{R R}^{G V}+K_{R R}^{C H} に お ~$ いて， $K_{R R}^{C V k は ~} K_{v V}$ のロッキングによる群杭効果を取り 入れるが, $K_{R R}^{C H}$ は単杭の $K_{R R}$ の単純和とする。杭心間隔 は大まかに $S_{x}=6.3 \mathrm{~m}, 6.7 \mathrm{~m} ; S_{y}=9.0 \mathrm{~m}$ とする。

6）内部減衰は建物, 地盤共に履歴型とし, 建物 : $\xi_{b}=$ 0.02 , 地盤： $\xi=0.02 ， 0.03$ を想定する。杭には内部減 衰はなく，杭頭は基礎スラブに剛に接合されているとす る。

解析モデルはFig. 10 に示すように，建物をせん断系 の 3 質点モデルとし，群杭による複素ばね $\left[K^{\mathrm{C}}\right]$ で支

\begin{tabular}{|c|c|c|c|c|c|c|}
\hline $\begin{array}{l}\text { Depth } \\
\text { (m) }\end{array}$ & $\begin{array}{c}\text { Soil } \\
\text { Description }\end{array}$ & $\begin{array}{c}\text { Thick } \\
\text { (m) }\end{array}$ & $\begin{array}{c}\rho \\
\left(\mathrm{g} / \mathrm{cm}^{\mathrm{a}}\right)\end{array}$ & $\nu_{s}$ & $\begin{array}{c}E_{\mathrm{s}} \\
\left(\mathrm{kgf} / \mathrm{cm}^{2}\right)\end{array}$ & $\begin{array}{c}\mu \\
\left(\mathrm{kgf} / \mathrm{cm}^{2}\right)\end{array}$ \\
\hline 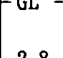 & $\begin{array}{r}\text { Debris \& } \\
\text { Clay }\end{array}$ & $\begin{array}{l}1.0 \\
1.8\end{array}$ & $\begin{array}{l}1.45 \\
2.00\end{array}$ & $\begin{array}{l}0.43 \\
0.43\end{array}$ & $\begin{array}{l}3320 \\
4580\end{array}$ & $\begin{array}{l}1160 \\
1600\end{array}$ \\
\hline & Sandy Silt & 2.1 & 1.85 & 0.49 & 1430 & 480 \\
\hline & Fine Sand & 2.7 & 1.95 & 0.49 & 1430 & 510 \\
\hline & Silty Sand & 3.1 & 1.85 & 0.49 & 800 & 270 \\
\hline & Silt & $\begin{array}{l}6.8 \\
3.9 \\
6.5\end{array}$ & $\begin{array}{l}1.55 \\
1.55 \\
1.75\end{array}$ & $\begin{array}{l}0.49 \\
0.49 \\
0.49\end{array}$ & $\begin{array}{r}390 \\
980 \\
1910\end{array}$ & $\begin{array}{l}130 \\
330 \\
640\end{array}$ \\
\hline $\begin{array}{l}27.9 \\
30.5\end{array}$ & $\begin{array}{l}\text { Sandy Silt } \\
\text { Clay }\end{array}$ & 5.7 & 1.70 & 0.46 & 2690 & 920 \\
\hline 33. & Clayey Sand & 3.2 & 1.80 & 0.45 & 3340 & 1150 \\
\hline $\begin{array}{l}36.8- \\
39.4- \\
42.3\end{array}$ & $\begin{array}{l}\text { Sandy Clay. } \\
\text { Clay } \\
\text { Clay/Sand }\end{array}$ & 7.8 & $1.80^{\circ}$ & 0.48 & 3400 & 1150 \\
\hline 44.6 & Fine Sand & 7.2 & 2.00 & 0.47 & 7350 & 2500 \\
\hline
\end{tabular}
持された 1 階部分に，次式で表される杭頭を静止させる に必要な駆動力 (driving force) の振幅で調和加振され
Soil profile and property

Fig. 9 Outline of a soil-pile-building system in case history

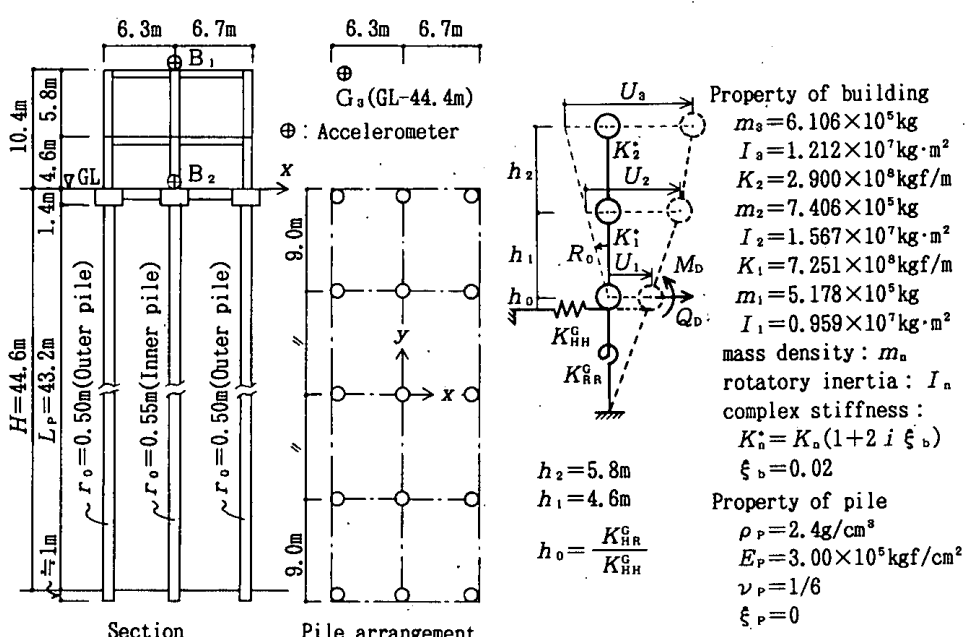

Fig. 10 Analytical model of soil-pile-building system 
る時の建物の短辺 $(x)$ 方向の応答を求める。

$$
\left\{\begin{array}{l}
Q_{D} \\
M_{D}
\end{array}\right\}=\left[\begin{array}{cc}
K_{H H}^{G}, & K_{H R}^{c}, \\
K_{H R}^{G}, & K_{R R}^{G H}
\end{array}\right]\left\{\begin{array}{c}
S_{H F} \\
S_{R F}
\end{array}\right\} U_{F} \cdots
$$

基礎固定時の建物の非減衰固有振動数は $f_{1}=8.6 \mathrm{~Hz}, f_{2}$ $=19.6 \mathrm{~Hz}$ である。また, 観測結果に用いられた地震は 20 回で, 1 階 $\left(B_{2}\right)$ 短辺方向の最大加速度は 4 75 gal 程度である。次の Figs.11，13 において，それらの地 震による観測結果の平均值を点線で，No. 32 の地震 $\left(B_{2}\right.$ での最大加速度 $13 \mathrm{gal}$ 程度）の観測結果を実線で表示 する。

1 階 $\left(B_{2}\right)$ に対する 3 階 $\left(B_{1}\right)$ の観測フーリエスペク トル比および本簡易評価法による伝達関数の振幅を Fig. 11 に示す。この図には杭基礎のばねの評価に群杭 効果を無視し, 単杭の杭頭インピーダンスの単純和とし た場合の結果も示している。この図から，本簡易評価法 による結果において，地盤-杭基礎-建物連成系の卓越振 動数は，観測結果による $7.5 \mathrm{~Hz}$ に近い値を示しており， 杭基礎のばねの評価としては妥当と考えられるが, 振幅 特性から群杭効果を考慮する必要があることが分かる。 また，Fig. 12 に示すように群杭基礎のばねは， $7 \mathrm{~Hz}$ あ たりから実部，虚部共に非常に大きくなり，群杭効果の 影響が強く現れ，建物の応答振幅が小さくなったと考え られる。

次に GL-44. $4 \mathrm{~m}$ で観測された波形（ $\left.G_{3}\right)$ に対する 1 , 3 階の観測フーリエスペクトル比と本簡易評価法による 伝達関数の振幅の比較を Fig. 13 に示す。この図から, 本簡易評価法による結果において,ピークの振動数は 1 , $2 ， 3$ および 5 次モードではよく近似しており，群杭基 礎での伝達関数の評価に用いた入力データの処理が妥当 であると考えられるが，高次モードになると差異が生じ 層状地盤の影響が現れている。また，4モードの振動数 は地盤一杭基礎連成による影響が現れ，正確にはとらえ られていない。ピークの振幅特性では，地盤の内部減衰 の評価によりかなりの変化が見られ，地震入力の大きさ に対する地盤の内部诚衰の評価が重要な課題となるが, 1 次モードを除けば観測された入力地震に対して, 大略 $\xi=0.02 \sim 0.03$ 程度でよく模擬できることが分かる。し かし，Fig. 11 に示すように地盤-杭基礎-建物連成系の

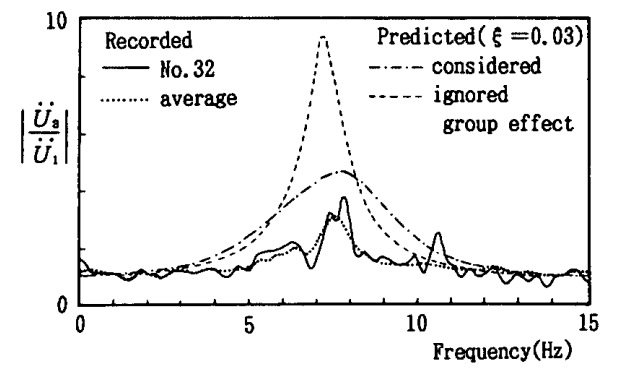

Fig. 11 Comparison of recorded and predicted Fourier acceleration spectrum ratios of $B_{1}\left(\ddot{U}_{3}\right)$ to $B_{2}\left(\ddot{U}_{1}\right)$
振幅特性の若干の差異により，3 階における 4, 5 次モ一 ドの振幅特性ではかなりの過大評価として現れており， 群杭効果および基礎の根入れ効果などのより精度の高い 評価による検討が今後の課題となる。

以上のように，実建物への適用例加，本簡易評価法

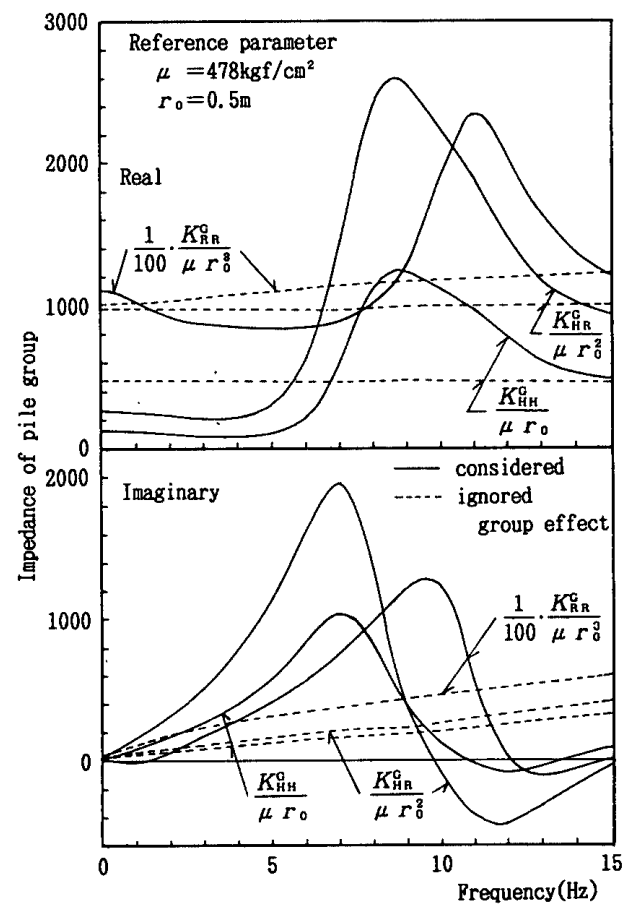

Fig. 12 Predicted impedances of pile group considered or ignored group effect $(\xi=0.03)$

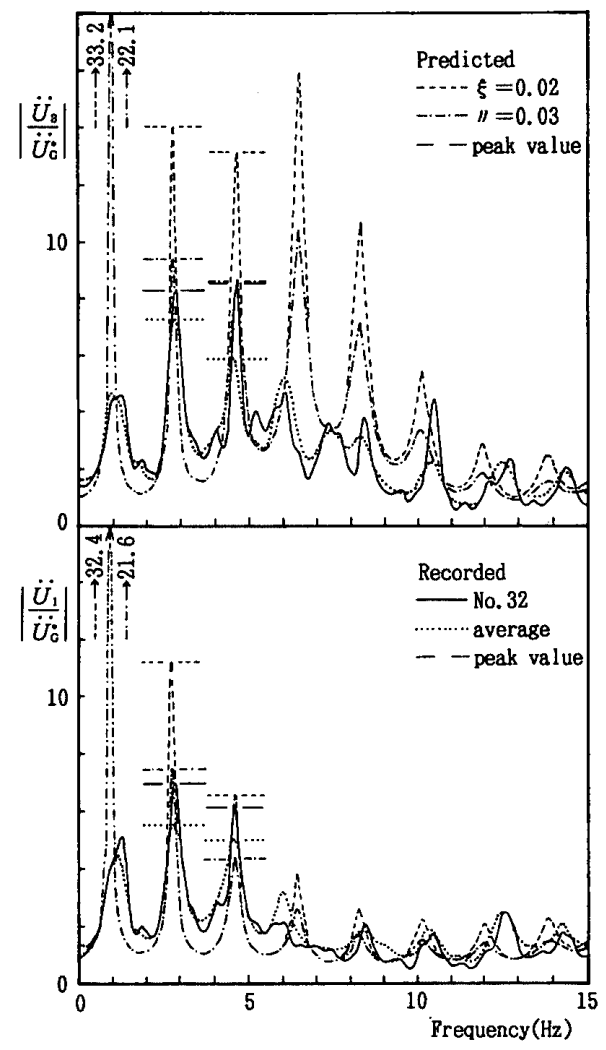

Fig. 13 Comparison of recorded and predicted Fourier acceleration spectrum ratios of $B_{1}\left(\ddot{U}_{3}\right)$ or $B_{2}\left(\ddot{U}_{1}\right)$ to $G_{3}\left(\ddot{U}_{G}^{*}\right)$ 
は実用上かなりよい精度で模擬でき, 解析パラメータの 変化に伴う地盤-杭基礎-建物連成系の複雑な動的特性の 評価において十分有用性があると考えられる。

\section{7. 結 論，}

単杭の鉛值・水平振動において，杭周と杭先端地盤の ウィンクラばねを簡単な表現で提案し; 杭のせん断変形 を考慮した杭頭のインピーダンスおよび伝達関数の振動 特性の一簡易評価法を提示した。提案する簡易評価法の 有用性は，広範囲のパラメトリックスタディから，厳密 解および他の解析結果との比較により精度の検証が行わ れ，また，杭基礎で支持された実建物への適用例により 確認された。本論文で取扱ったパラメー夕範囲において, 結論として次のように要約する。

1）杭先端地盤のウィ:ンクラばねを（21）式の簡易式と して提案し，その評価は $10 \%$ 程度の誤差内にある。

2）杭周地盤のウィンクラばねの（28）式で提案する簡 易評価法は，有効杭長・層厚の概念を導入することによ り，静的・動的問題におけるそれそれれの既往の簡易評価 法を,柔長杭はもとより表層地盤中の柔長でない支持杭, 浮杭にも適用可能にし，静的・動的にも一貫したより一 般化された一簡易評価法として位置づけられる。

3）杭周地盤のウィンクラばねの（29）式による静的な 簡易評価は，非常に短い杭を除けば $10 \%$ 程度の誤差に 納まっている。

4）静的な杭頭インピーダンスの簡易評価は，おおむね $\pm 10 \%$ 程度の誤差に納まっている。

5）動的杭頭インピーダンスの簡易評価法は，表層地盤 の 1 次共振点および Airy 相付近を除けば実用上十分な 精度を有しており, 既往の動的平面ひずみ解による評価 法を柔長杭および低振動数領域まで適用可能にした一簡 易評価法として位置づけられる。

6）伝達関数の簡易評価法は, 水平振動における柔で長 い杭ではその精度が高振動数領域で悪くなるものの，実 用上十分な精度を有している。

7）地震観測された杭基礎建物への本簡易評価法の適用 例から, 実用上かなりよい精度で模擬でき, 解析パラメー 夕の変化に伴う地盤-杭基礎-建物連成系の複雑な動的特 性の評価においても十分有用となる。

\section{謝 辞}

本研究を進めるにあたり，終始有益な御助言を頂きま した神戸大学名誉教授 堯天義久博士，神戸大学元教授 故水畑耕治博士に深甚の謝意を表します。

最後に，貴重な解析結果および地震観測結果を引用さ せて頂いた方々に対して心より御礼申しあげます。

\section{引用・参考文献}

1) Terzaghi, K. : Evaluation of Coefficients of Subgrade
Reaction, Geotechnique, Vol.5, No.4, pp. 297 326, 1955.

2）杉村義広：杭頭回転拘束度および杭長を考慮した杭の水 平抵抗理論解, 日本建築学会構造系論文報告集, 第 365 号, pp. 132 143, 昭和 61 年 7 月.

3）日本道路協会：道路橋示方書・同解説, IV下部構造編, 丸善, 昭和 55 年 5 月.

4）日本建築学会：建築基礎構造設計指針，丸善， 1988 .

5) Francis, A: J. : Analysis of Pile Groups with Flexural Resistance, Journal of Soil Mechanics and Foundations Division, ASCE, Vol.90, No.SM 3, pp. 1 32, 1964.

6) Butterfield, R. and Banerjee, P.K. : The Elastic Analysis of Compressible Piles and Pile Groups, Geotechnique, Vol.21, No.1, pp.43 60, 1971.

7) Banerjee, P.K. and Davies, T.G. : The behaviour of axially and laterally loaded single piles embedded in nonhomogeneous soils, Geotechnique, Vol.28, No. 3, pp. 309 326, 1978.

8) Poulos, H.G. : Behavior of Laterally Loaded Piles: I-Single Piles, Journal of Soil Mechanics and Foundations Division, ASCE, Vol.97, No. SM 5, pp.711 731, 1971.

9) Randolph, M.F. and Wroth, C. P.: Analysis of Deformation of Vertically Loaded Piles, Journal of Geotechnical Engineering Division, ASCE, Vol. 104, No. GT 12, pp. $1465 \div 1488,1978$.

10) Penzien, J., Scheffey, C.F. and Parmelee, R. A. : Seismic Analysis of Bridges on Long Piles, Journal of Engineering Mechanics Division, ASCE, 'Vol.90, No. EM 3, pp. 223 254, 1964.

11) Novak, M. : Dynamic Stiffness and Damping of Piles, Canadian Geotechnical Journal, Vol.11, No.4, pp. 574 - 598, 1974

12) Novak, M. : Vertical Vibration of Floating Piles, Journal of Engineering Mechanics Division, ASCE, Vol. 103, No. EM 1, pp. 153 168, 1977.

13) Takemiya, M. and Yamada, Y. : Layered Soil-PileStructure Dynamic Interaction, Earthquake Engineering and Structural Dynamics, Vol.9, pp.437-457, 1981.

14) Novak, M., Nogami, T. and Aboul-Ella, F. : Dynamic Soil Reaction for Plane Strain Case, Journal of Engineering Mechanics Division, ASCE, Vol. 104, No. EM 4, pp. 953 959, 1978.

15) Novak; M. and El Sharnouby, B. : Stiffness Constants of Single Piles, Journal of Geotechnical Engineering, ASCE, Vol. 109, No. 7, pp. 961 974, 1983.

16) Kuhlemeyer, R.L. : Static and Dynamic Laterally Loaded Floating Piles, Journal of Geotechnical Engineering Division, ASCE, Vol. 105, No. GT 2, pp. 289 $\sim 304,1979$.

17) Dobry, R., Vicente, E., O'Rourke, M. J. and Roesset, J.M. : Horizontal Stiffness and Damping of Single Piles, Journal of Geotechnical Engineering Division, ASCE, Vol. 108, No. GT 3, pp. 439 459, 1982.

18) Gazetas, G. : Seismic response of end-bearing single piles, Soil Dynamics and Earthquake Engineering, 
Vol. 3, No. 2, pp. 82 93, 1984.

19) Nozoe, H., Gyoten, Y., Mizuhata, K. and Fukusumi, T. : A Physical Approximation for the Pile-Head Impedances of a Soil-Pile System in the Low Frequency Range, 第 7 回日本地震工学シンポジゥム, pp. 997 $1002,1986$.

20) Nozoe, H., Gyoten, Y., Mizuhata, K. and Fukusumi, T. : Characteristics of Pile Head Impedance and Its Approximate Estimation in Vertical Vibration, 神戸大 学大学院自然科学研究科紀要, No. 6-A, pp. 7 22, 1988.

21) Nozoe, H., Gyoten, Y., Mizuhata, K. and Fukusumi, T. : Estimation of Impedance and Transfer Functions for End Bearing and Floating Piles, Proceedings of 9 th World Conference on Earthquake Engineering, Vol. III, pp. $563 \sim 568,1988$.

22) Nozoe, H., Gyoten, Y. and Fukusumi, T. : Dynamic Analysis of a Soil-Pile System by the Finite FourierHankel Transformation Method -Case of a Floating Pile in Horizontal Vibration -, Theoretical and Applied Mechanics, University of Tokyo Press, Vol.33, pp. 377 $\sim 392,1985$.

23) Nozoe, H., Gyoten, Y. and Fukusumi, T. : Dynamic Analysis of a Soil-Pile System by the Finite FourierHankel Transformation Method - Case of a Floating Pile in Vertical Vibration一, 神戸大学大学院自然科学 研究科紀要, No. 3-A, pp. 35 48, 1985.

24) Kobori, T., Minami, R. and Bada, K. : Dynamic Behavior of a Pile under Earthquake Loading, Proceedings of International Conference on Recent Advances in Geotechnical Earthquake Engineering and Soil Dynamics, Vol. II, pp. 795 800, 1981.

25）小堀鐸二, 南井良一郎, 馬場研介：基礎入力を受ける杭 の上下振動特性について, 第 31 回応用力学連合講演会講 演論文抄録集，pp. 347－348，1981.

26) Coper, G. R. : The Shear Coefficient in Timoshenko's Beam Theory, Journal of Applied Mechanics, ASME, Vol. 33, No. 2, pp. 335 340, 1966.

27) Gazetas, G. : Analysis of machine foundation vibrations : state of the art, Soil Dynamics and Earthquake Engieering, Vol.2, No.1, pp.-2 42, 1983.

28）野添久視，日下部警，福住忠裕：粘弾性表層地盤中に設 置された単杭の鉛直振動特性, 日本建築学会構造系論文 報告集，第 424 号，pp. 143 155，1991 年 6 月.

29）松岡 理，八幡夏恵子：三次元均質等方弾性体動問題の 基本解とその応用 Mindlin 問題その 1, 日本建築学会論 文報告集，第 288 号, pp. $73 \sim 84$, 昭和 55 年 2 月.

30）日本建築学会：構造物と地盤の動的相互作用シンボジウ 厶, pp. $77 \sim 92,1985.4 .16$.

31) Dobry, R. and Gazetas, G. : Simple Method for Dynamic Stiffness and Damping of Floating Pile Groups, Geothechnique, Vol. 38, No.4, p.557 574, 1988.

\section{Appendix}

\section{A. 1 Randolph 5の簡易式 ${ }^{9)}$}

Randolph らは，杭周の鉛直方向ウィンクラばね係数を静的 平面ひずみ解から次式のように簡易評価している。

$$
\frac{1}{k_{v}}=\frac{r_{0}}{\mu} \ln \left(\frac{r_{m}}{r_{0}}\right) ; r_{m}=2.5 L_{P}\left(1-\nu_{s}\right) \cdots
$$

\section{A. 2 Francis $の$ 簡易式 5 )}

Francis は，杭周の水平方向地盤反力係数として，Vesić の簡 易式を 2 倍した次式によって簡易評価している。

$$
K_{C H}=1.30 \frac{E_{S}}{1-\nu_{S}^{2}} \cdot \sqrt[12]{\frac{E_{S} B^{4}}{E_{P} I_{P}}} ; \text { 杭幅 } B=2 r_{0}
$$

(1991 年 8 月 21 日原稿受理, 1992 年 5 月 19 日採用決定) 